الإحتياجات المعرفية الإرشادية الزراعية لشباب الحخيجين فى إنتاج وتداول محصول الفول السودالن بمنقة البستان بمحافظة البحيرة

جميل محمد شرف الدين، عصام عبد اللطيف مبروك عمار، عبد العاطى هميدة سكر الحمره 1

لشباب الحرييين المبحوثين للتوصيات الفنية لإنتاج وتداول محصــول

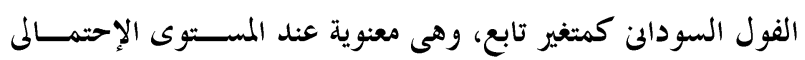
$\cdot \cdot, \cdot 1$

-تو جد علاقة بين كل من مستوى العائد المتحقق مـن محصــول

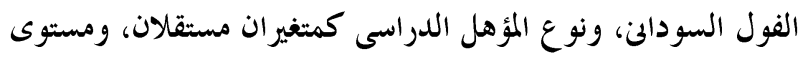

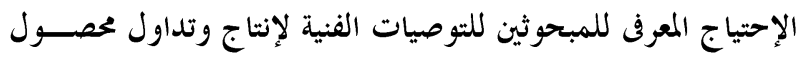

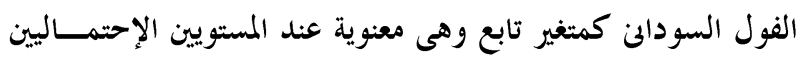

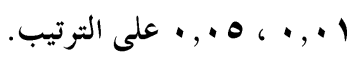

-تمثلت أبرز معوقات انتاج وتسويق محصول الفول الســوداني في

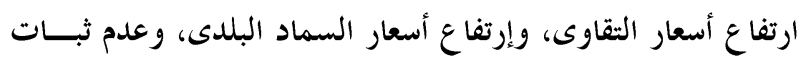

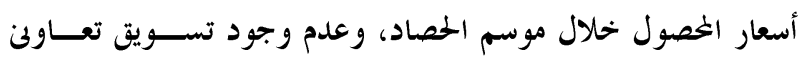

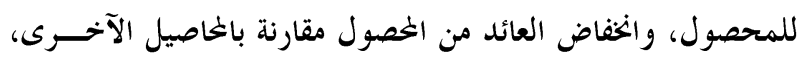

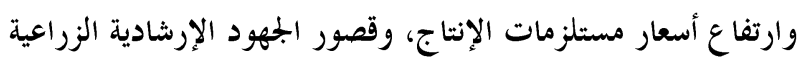

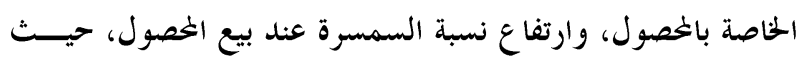

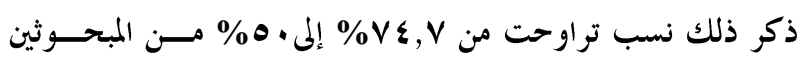

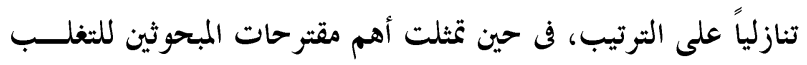

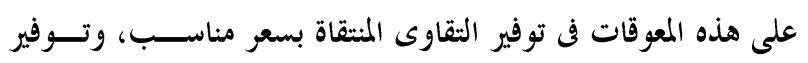

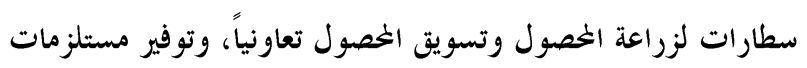

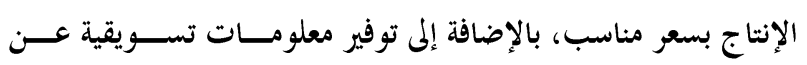

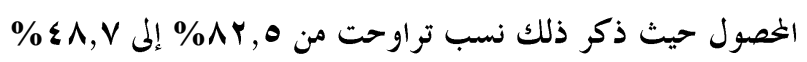

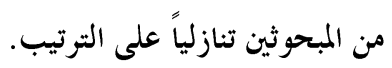

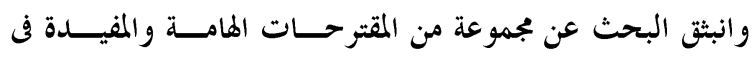
الإرتقاء بعملية انتاج وتداول وتسويق محصول الفول السوداني.

\section{المقدمــــــة والمثكلة البحثيـــة}

تعتبر الزيوت النباتية الغذائية مكون أساسى لغذاء الإنسان وأحد الفحد

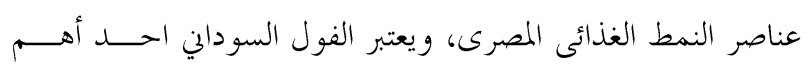

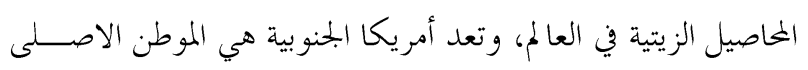

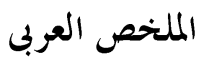

أجرى هذا البحث هـدف تحديد مستوى الإحتياج المعرف لشباب المباب

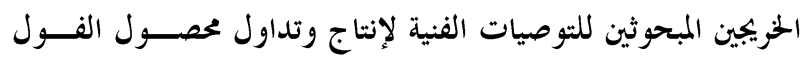

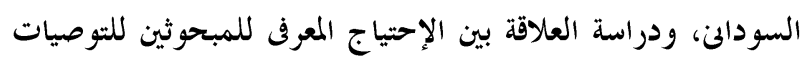

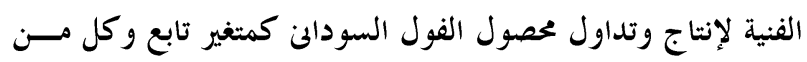

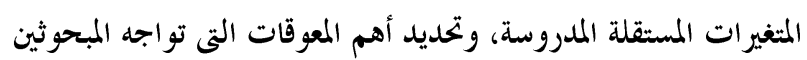

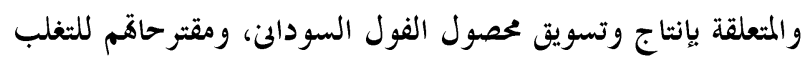

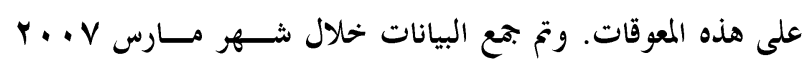

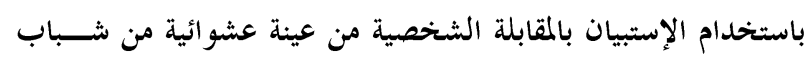

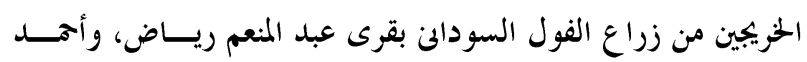

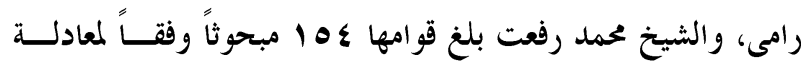

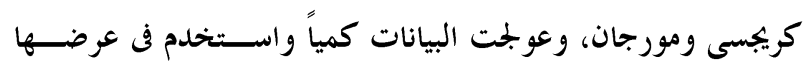

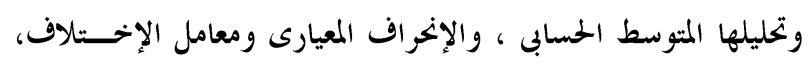

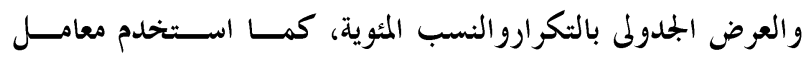

الإرتباط البسيط ومربع كاى (كاب ).

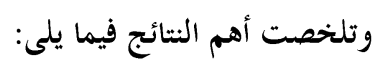

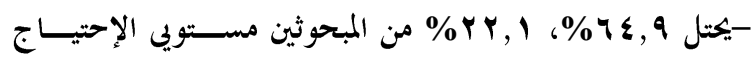

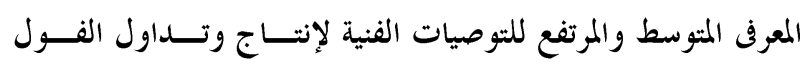

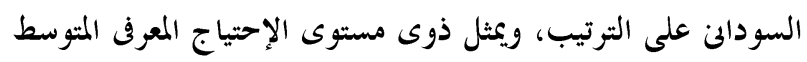

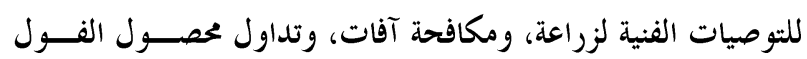

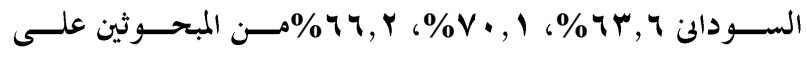
الترتيب، فل حين يمثل ذوى مستوى الإحتياج المعرف المرتفع للتوصيات

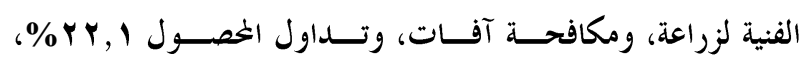

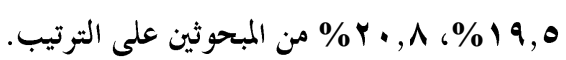

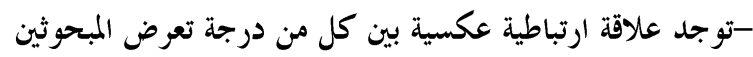

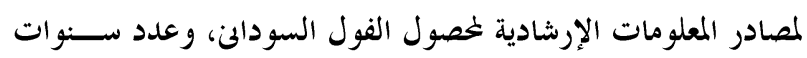

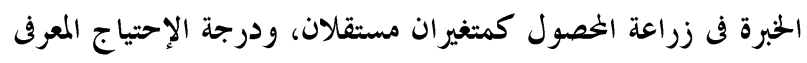




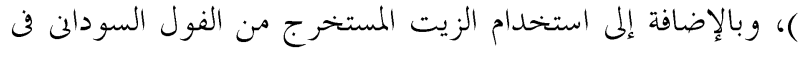

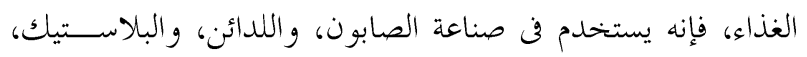

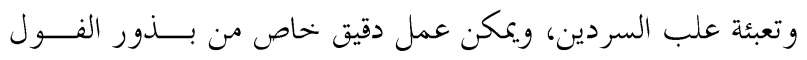

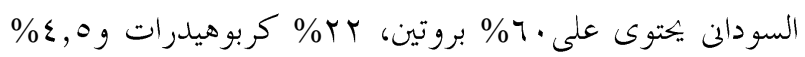

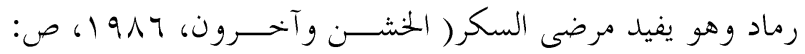

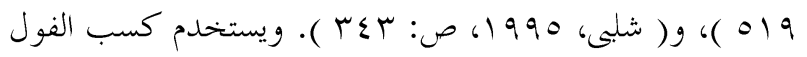

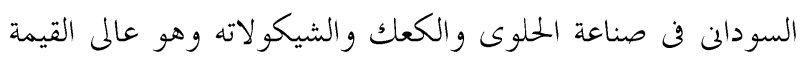

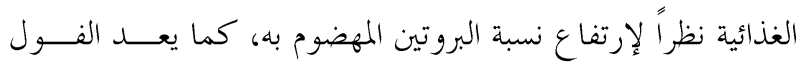

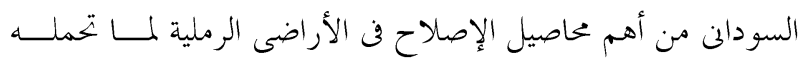

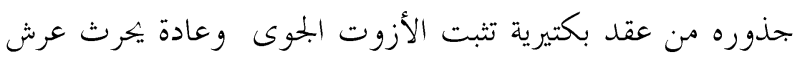

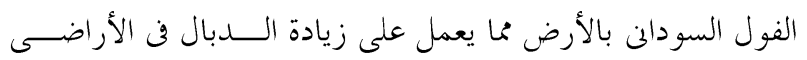

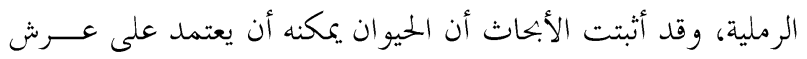

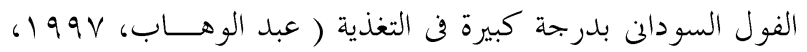

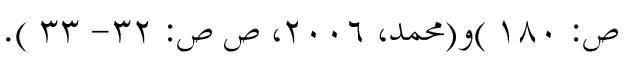
وقد بلغت المساحة المترعة بالفول السودانف في محافظة البحيرة

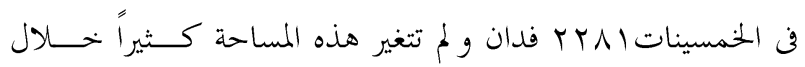
العقود التالية حتى هاية القرن العشرين، إلا أها بدأت تزداد في بداية

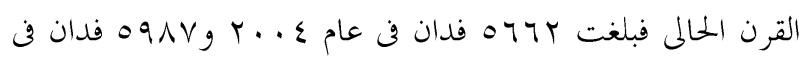

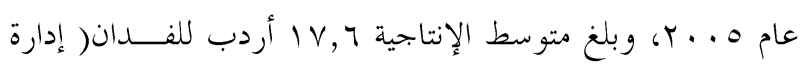

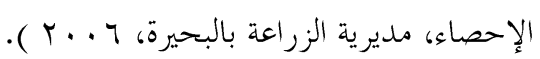
ولتحقيق إنتاجية عالية من الفول الســـودانف يوصــى برنــامج

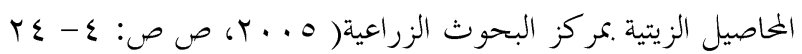

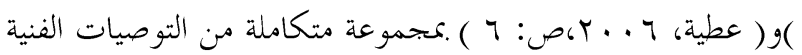
للمحصول يمكن تلخيصها فيما يلى: أولاً: التوصيات الفنية لزراعة الخصول: 1- الأصناف: ينصح بزراعة الأصــناف جيـزة ه، وجيــزة 7،

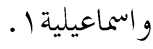

r- الأرض المناسبة: تجود زراعة الفول السودانف في الأراضى الرملية والصفر اء الخفيفة جيدة الصرف. r- الدورة الزراعية: ثلاثية وثنائية على الأقل. ع - ميعاد الزراعة: من منتصف شهر ابريل إلى منتصف شهر مايو.
هذا المحصول، حيث أكتشفت حفريات قديمة لثماره فن بيرو، كما

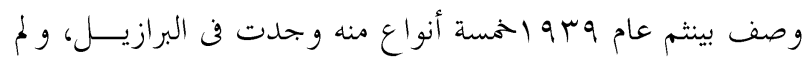

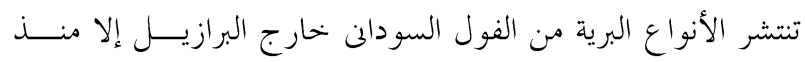

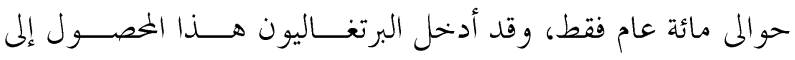

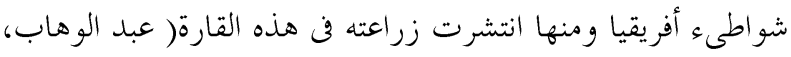

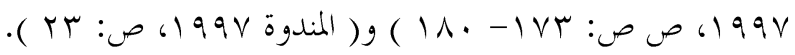
وادخل الفول السودانى حديثا المى مصر في اوائل القرن التاسع عشر

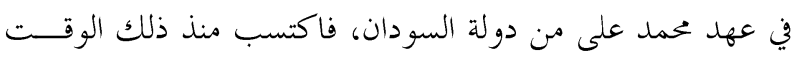

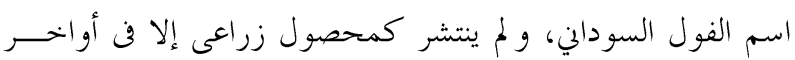

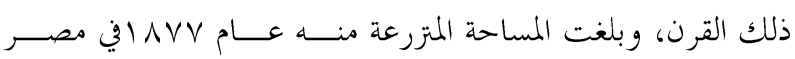

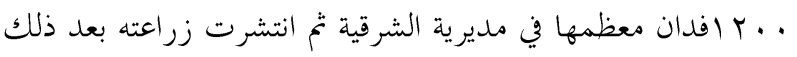

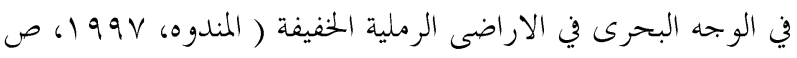

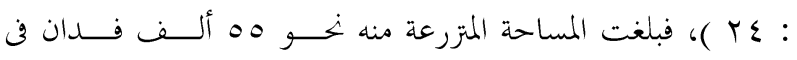

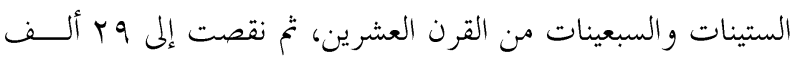

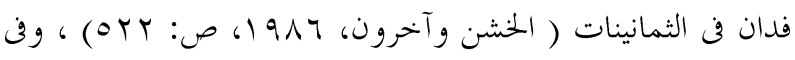

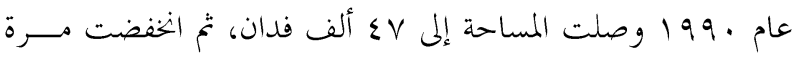

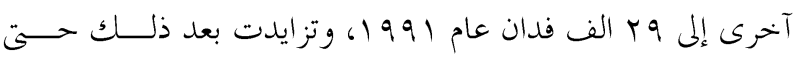

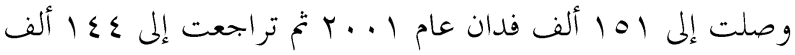

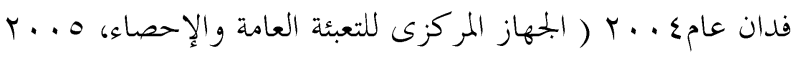
$\cdot(1 \leq 9: ص 6$

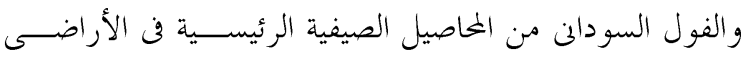

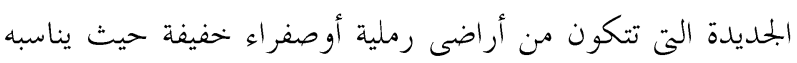

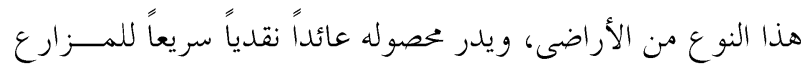

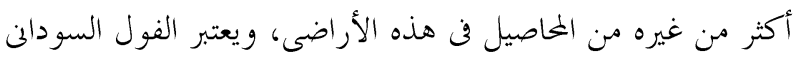

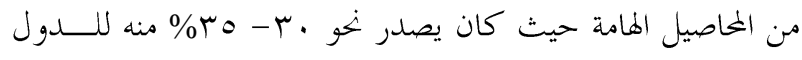

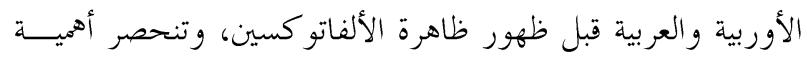

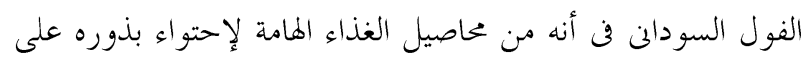

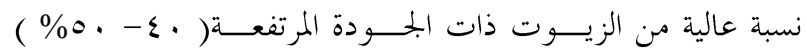
بالإضافة إلى جودة الكسب الناتج من البذور( بعد استخراج الزيت)

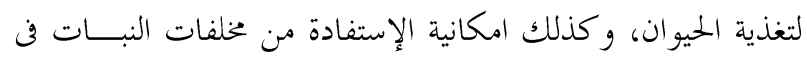

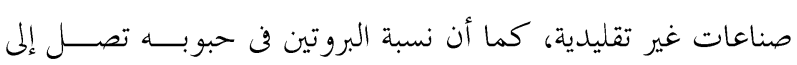
\% r .

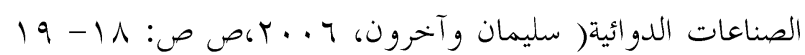


يتم حصاد الفول السوداني عندظهور علامات النضج المتمثلة في

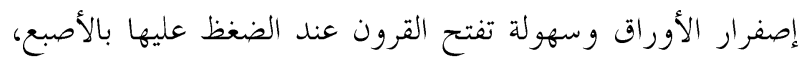

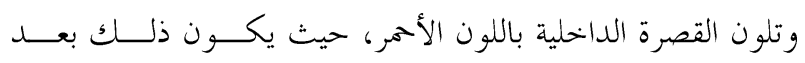

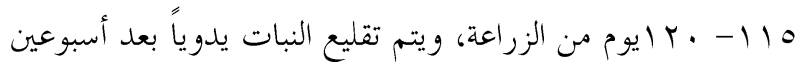

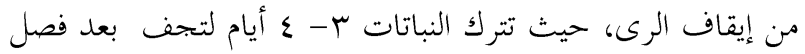
القرون فن طبقة سمكها ·. سمه، وتستمر عملية التجفيف . 1- 10

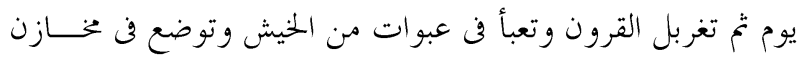

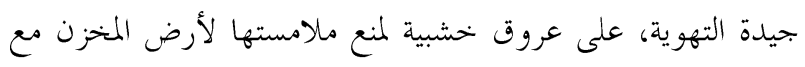
ترك مسافات بينية بين الصفوف لسهولة التهوية.

ولعل تحديد الإحتياجات المعرفية للخريجين للتوصـيـات الفنيــة

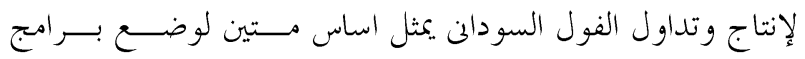
إرشادية هدف إلى اشباعها، وبالتالى زيادة قدرة الخريبين على تنفيذ

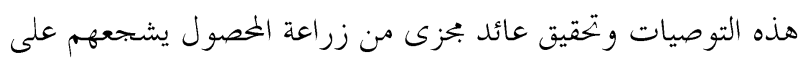

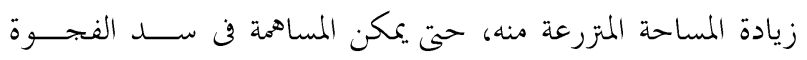

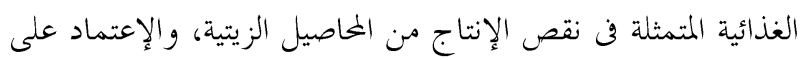

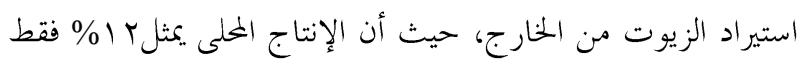

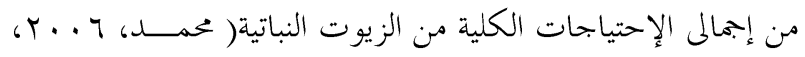
ص: ب M ) )، إذ يؤ كد ( Maunder ( 1972,p.82 على أن البرنامج

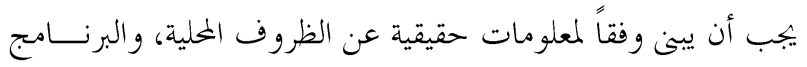

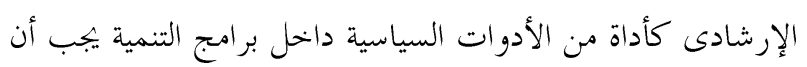

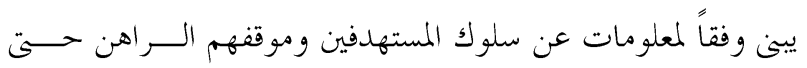

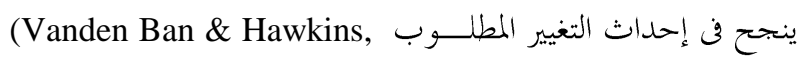
.( 1988, p.203

ويعرف علماء النفس الحاجة بأها عرض نفسى Psychological

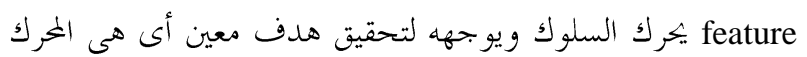
و الموجه للسلوك الإنسانى (Ian Gough, 2007, p. 25) . و والحاجة

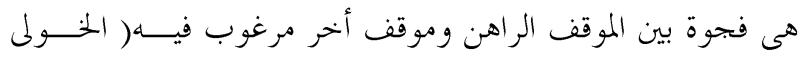

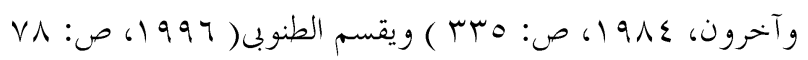

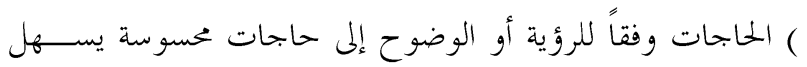

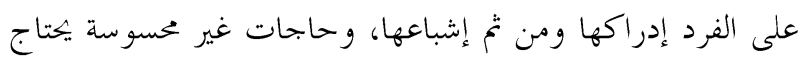
الفرد إلى من يبصره هـا ويهولها إلى حاجات محسوسة ، ويشير بدران

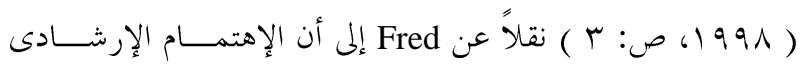

$$
\text { 0- معدل التقاوى: يحتاج الفدانه ع- . ه كجم بذرة. }
$$

ج- الزراعة: يستخدمץ-r كيس لقاح بكتيرى لتقاوى الفدان تخلط

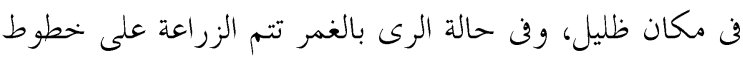

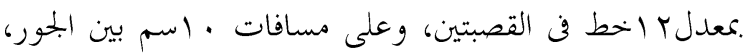
مع وضع بذرة واحدة فن كل جورة، ويجرى الرى فن نفس يوم

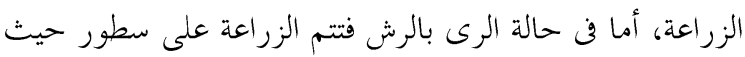

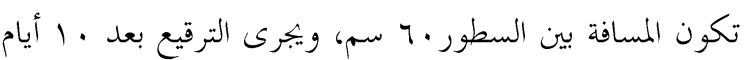

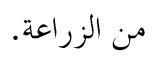

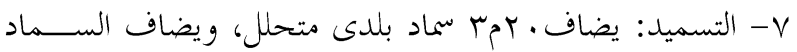

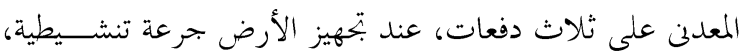

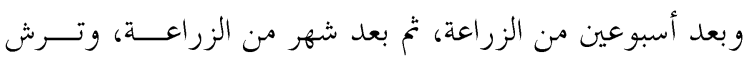

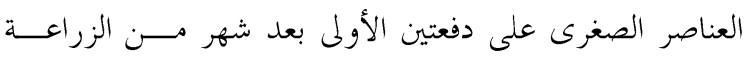

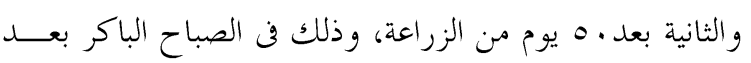

$$
\text { تطاير الندى .معدل ه, •·جرام للتر. }
$$

1- الرى: في حالة الرى بالغمر يجرى الرى كلع - ب أيسام، وفي

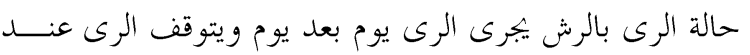
اكتمال النضج قبل الحصاد بأسبوعين.

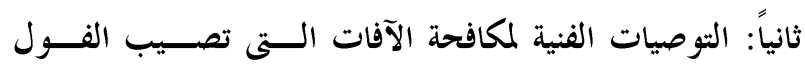

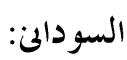
لمكافحة الحشائش يمكن إجراء رية كدابة لكــى يــتم إنبـــات

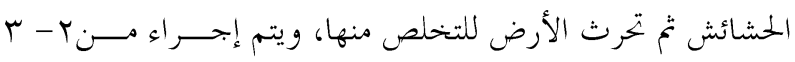

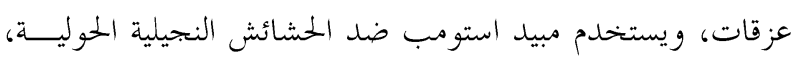

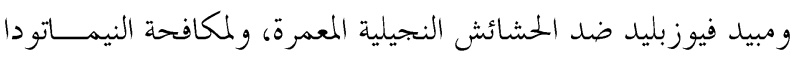

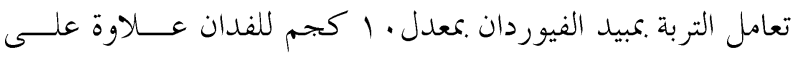

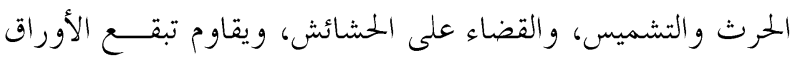

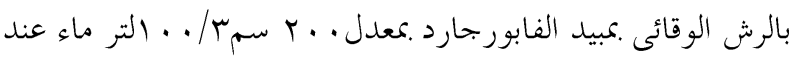

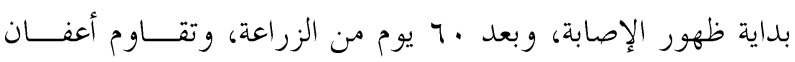
الثمار بفرز التقاوى قبل الزراعة واستبعاد المصاب منها، و الإعتدال في الرى، واستخدام مطهر فطرى مناسب بالإضافة إلى اتباع دورة ثلاثية. ثالثاً: التوصيات الفنية لتداول الخصول: 
وتبين للحفى (990 1990 : ( ) أن أهم المشكلات المجتمعيسـة

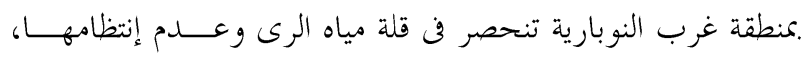
وصعوبة تسويق الحاصلات الزراعية، وعدم توفر الأجهزة الإرشادية

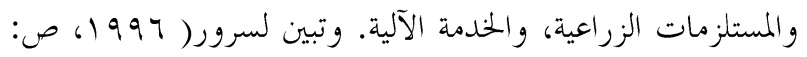

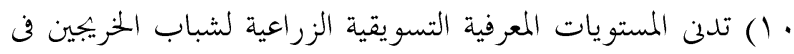
بعض قرى بنجر السكر، كما أظهر المبحوثون احتياجاهم التدريبية

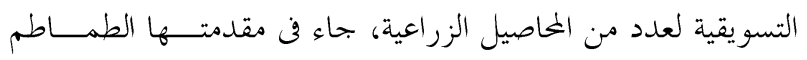

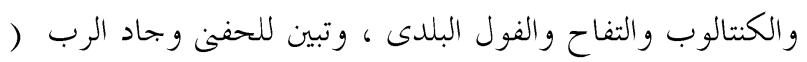

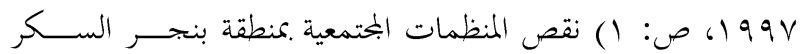

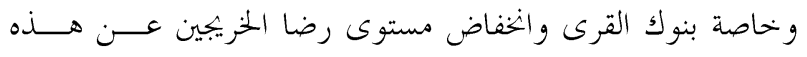

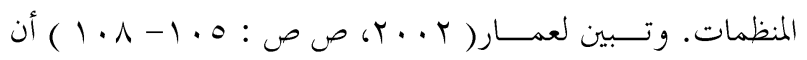

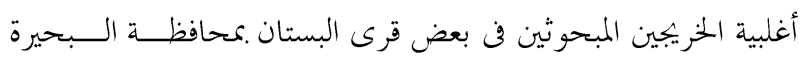

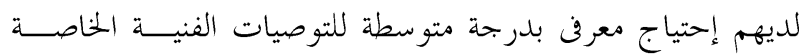

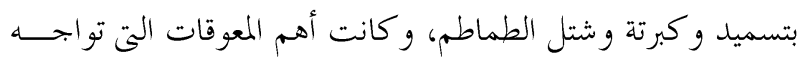

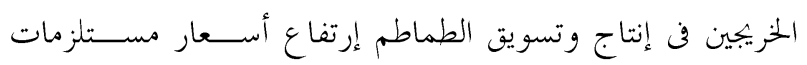

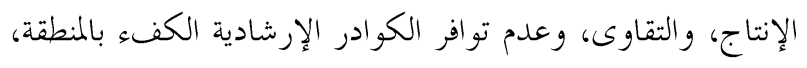

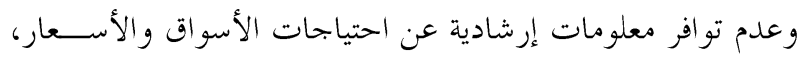
وعدم وجود جمعيات لتسويق الخضر، وتحكم بتحار التجزئة. مما سبق يتبين أن الخريجين في الأراضى الجديدة يعـانون مــنـ

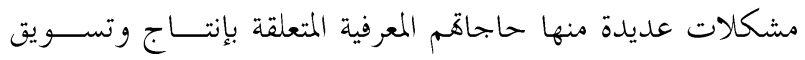

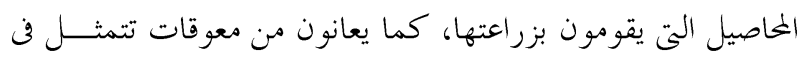

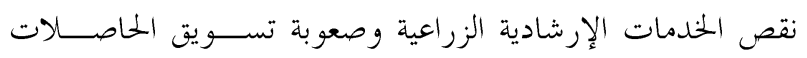

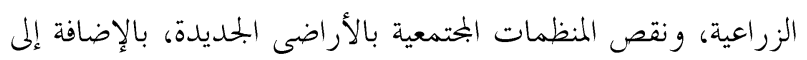

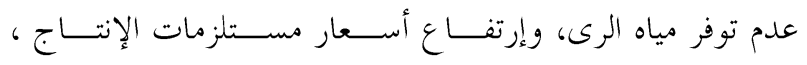

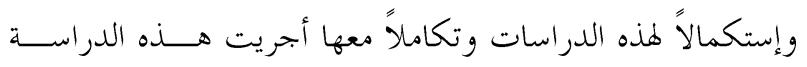
لإجحابة على بعض التساؤلات حول ماهية مستوى الإحتياج المعرف

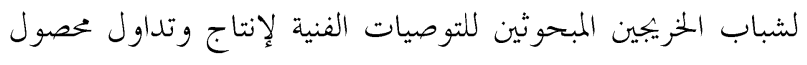
الفول السودانى؟ وماهية المتغيرات ذات العلاقة باحتياجهم المعرفى في لئنين

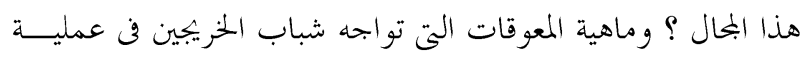

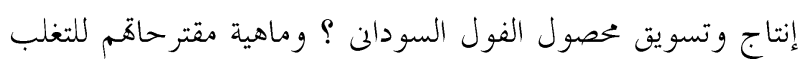
على هذه المعوقات؟، خاصة وأن متوسط إنتاجية الأراضى الجلديدة من مصول الفول السودانى الصيفى يقل عن مثيله بالأراضى القديمة

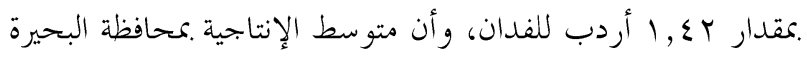

لايجب أن يقتصر على الجانب المحسوس من الحاجات الحقيقية فقط،

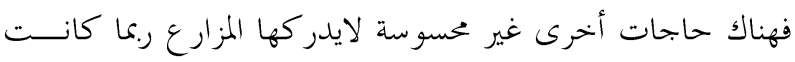
أساسية وهامة ولها فاعليتها الكبرى في حياته. و يفرق(Clark,2008) بين الحاجة need و الطلب want، فيذكر

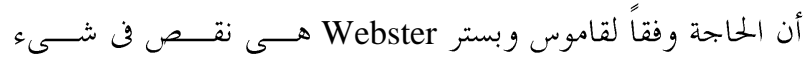

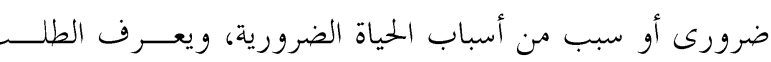

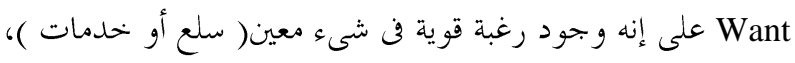

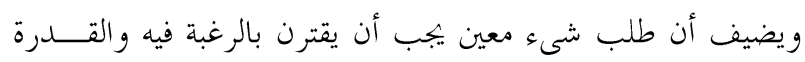

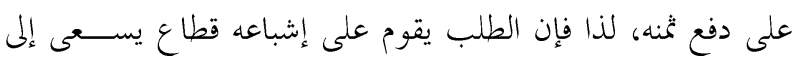

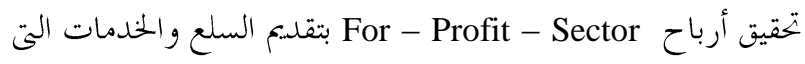

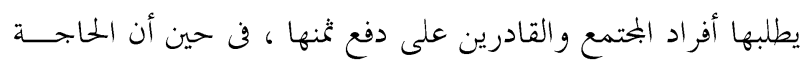

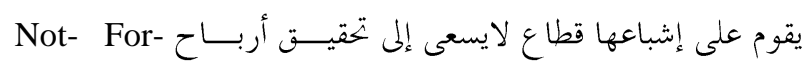

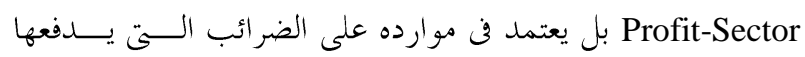

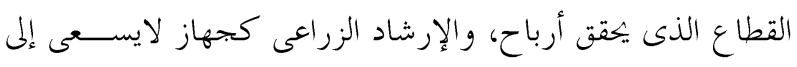

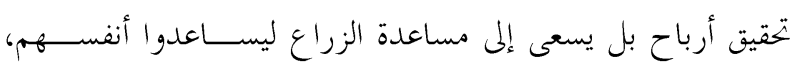

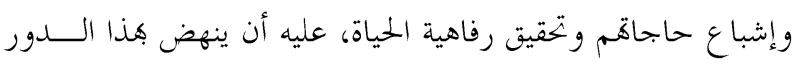

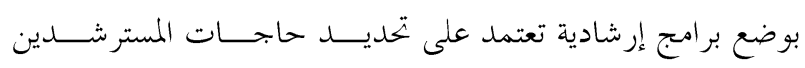

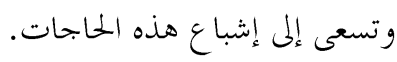
وقد تناولت دراسات عديدة تحديد الإحتياجـــات الإرشــادية

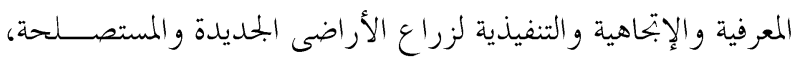

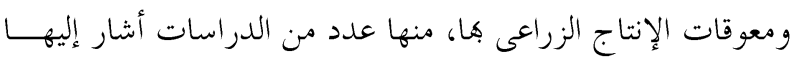

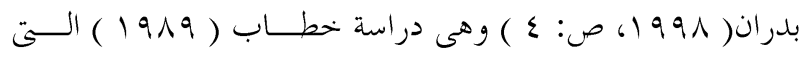
عكست حاجة الخريجين المبحوثين بمشروع جنو إنى دراس التحرير إلى رفع

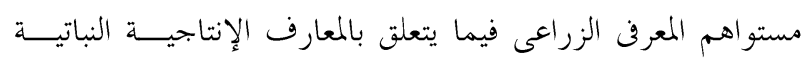

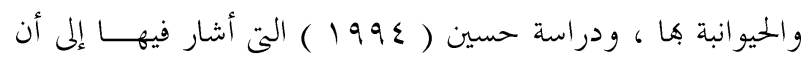

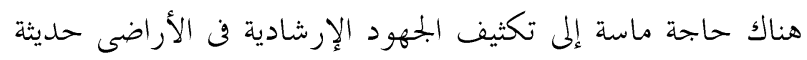

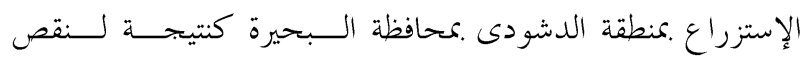

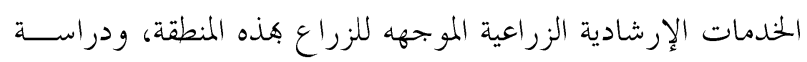

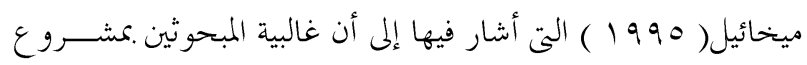

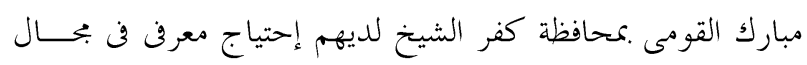
زراعة وإنتاج مصول بنجر السكر. 
تابع و كل من المتغيرات المستقلة المتمثلة فن النشأة، ونوع المؤهل الدراسى، ومستوى العائد المتحقق من محصول الفول السوداني

$$
\text { كمتغيرات مستقلة. }
$$

\section{الأسلوب البحثى}

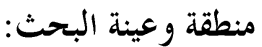

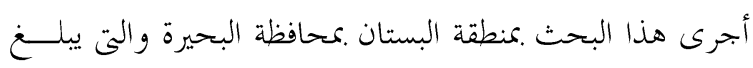

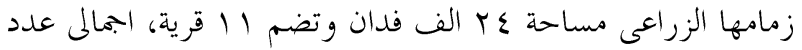

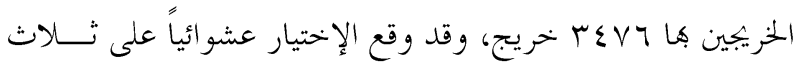

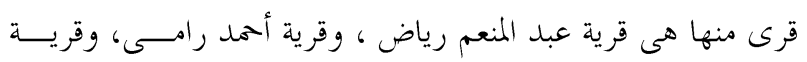

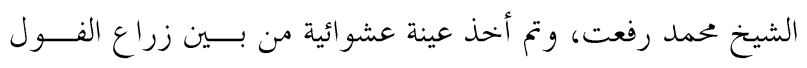

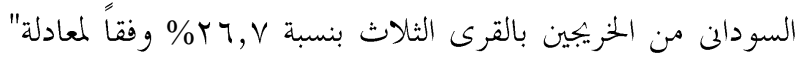

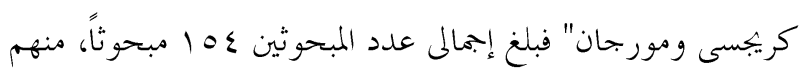

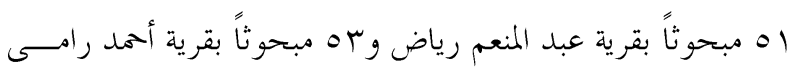

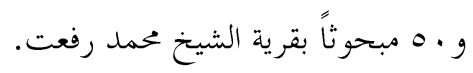

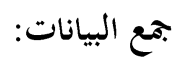

استخدمت إستمارة إستبيان بالمقابلة الشخصية بعد تصـميمها

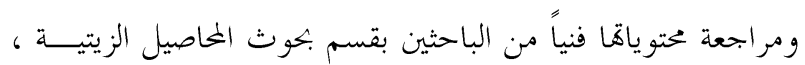

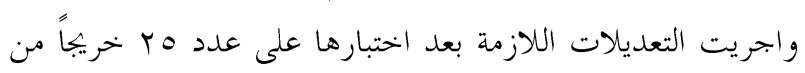

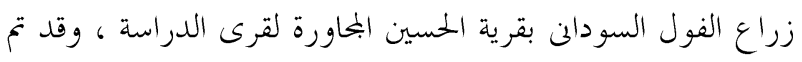

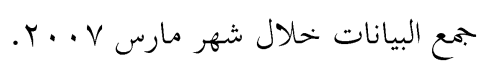

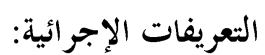

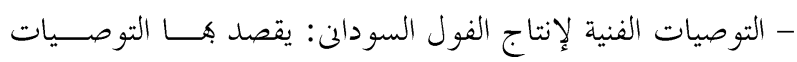
الفنية الخاصة بعمليتى زراعة الخصول ومكافحة آفاته.

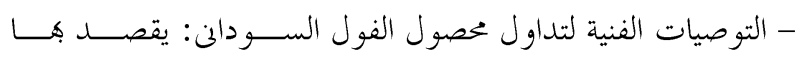
التوصيات الفنية الخاصة بحصاد وبتفيف وتعبئة وتخزين المحصول. - نوع المؤهل الدراسى: يقصد به إن كان زراعى عالى أو متوسط ، أو غير زراعى عالى أو متوسط.

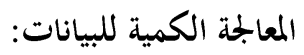
أولاً: المتغير التابع:
ينخفض عنه على مستوى الجمهورية معقدار \& ؟, ا أردب للفدان)

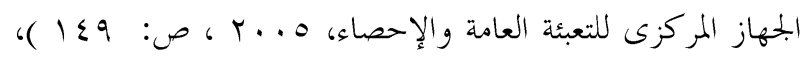

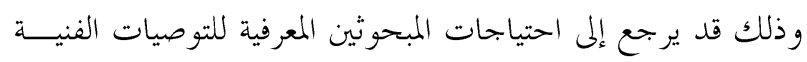

$$
\text { لإنتاج وتداول محصول الفول السودانى. }
$$

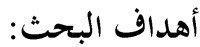

1- تحديد مستوى الإحتياج المعرف لشباب الخـــيجين المبحــــثين للتوصيات الفنية لإنتاج وتداول محصول الفول السوداني. r- دراسة العلاقة بين الإحتياج المعرف للمبحوثين للتوصيات الفنية

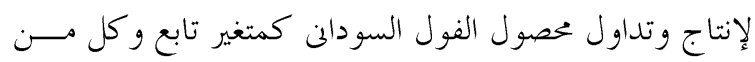
خصائصهم المدروسة المتمثلة في نوع المؤهل الدراسى، والنشأة،

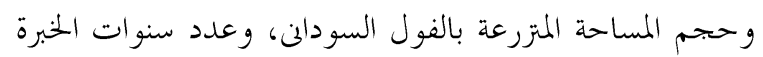

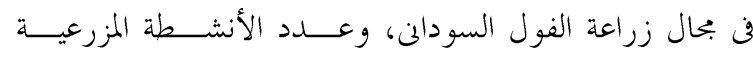

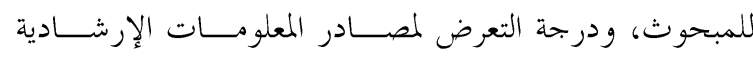

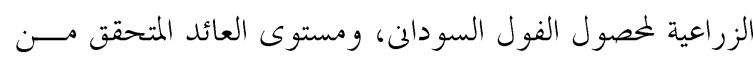
محصول الفول السودانى كمتغيرات مستقلة.

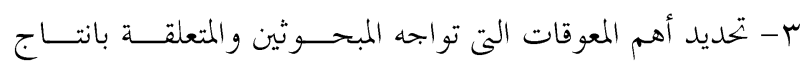

$$
\text { وتسويق مصصول الفول السودانى. }
$$

ع - تحديد أهم مقترحات المبحوثين للتغلب على معوقـــات إنتــاج

$$
\text { وتسويق محصول الفول السودانى. }
$$

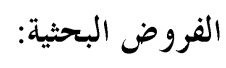

لتحقيق الهدف البحثى الثان تم صـــياغة الفرضـــان البحثيــان

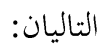

ا - توجد علاقة إرتباطية معنوية بين درجــــة الإحتيــاج المعــرفى

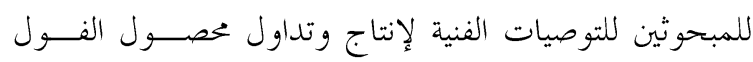

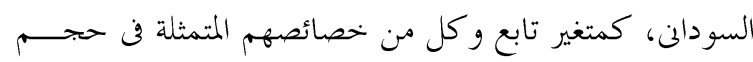

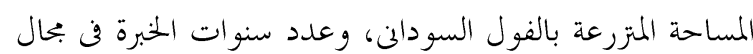

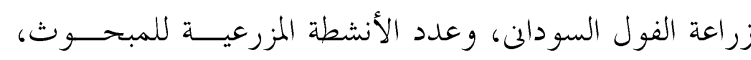

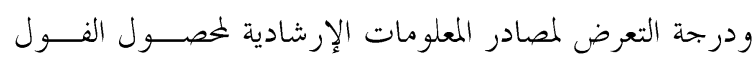

$$
\text { السوداني كمتغيرات مستقلة. }
$$

ץ- توجد علاقة معنوية بين مستوى الإحتياج المعرفى للمبحسـوثين

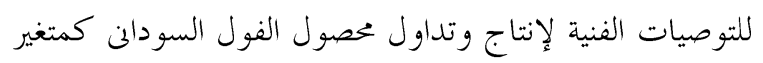


والحاصل على بكالوريوس غير زراعى درجتان، والحاصل على دبلوم غير زراعى درجة واحدة. r- النشأة: أعطى المبحوث درجتان في حالة النشأة الريفية، ودرجة واحدة في حالة النشأة الحضرية . r- حجم المساحة المترعة بالفول السودانى: قيس باستخدام الرقم رماتم الخام للمساحة المترعة .محصول الفول السوداني لأقرب فدان. ع - عدد سنوات الخبرة في بحال زراعة الفــول الســوداني: قــيس

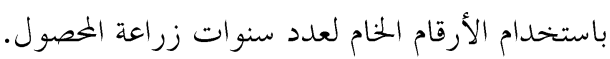
ه- عدد الأنشطة المزرعية للمبحوث: قيس باستخدام الأرقام الخنام

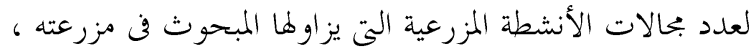

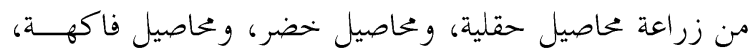

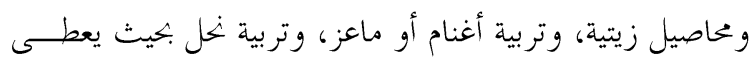

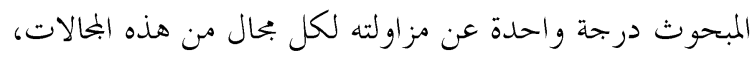

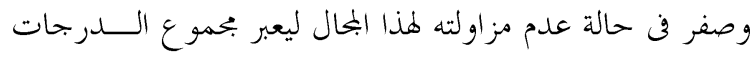
عن عدد الأنشطة المزرعية التى يز اولها المبحوث. 7- درجة التعرض لمصادر المعلومات الإرشادية لمصــول الفــول

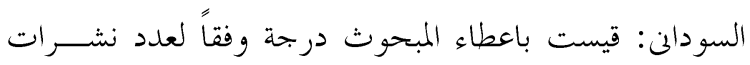

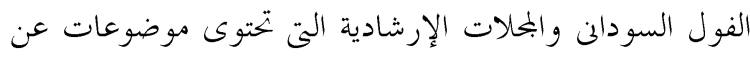

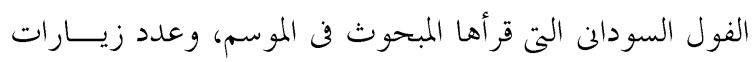

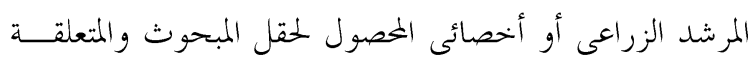

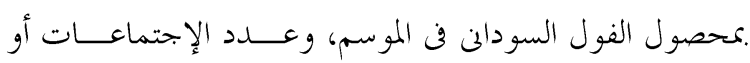

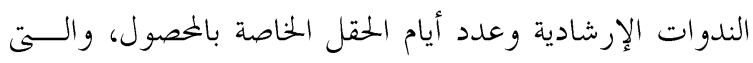

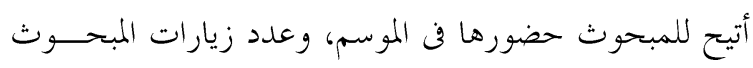

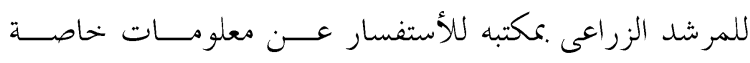
بالمصول فن الموسم، ليعبر بحموع الدرجات عن هذا المتغير. V- مستوى العائد المتحقق من المحصول: قيس باعططـاء المبحــــوث

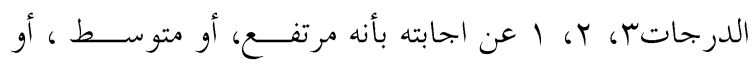

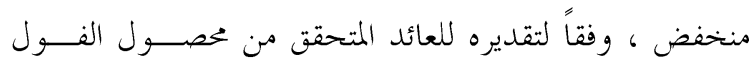

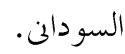

أدوات التحليل الإحصائى:
تم قياس درجة الإحتياج المعرف للمبحوثين للتوصـيـات الفنيــة

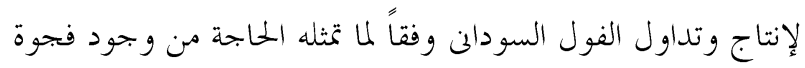

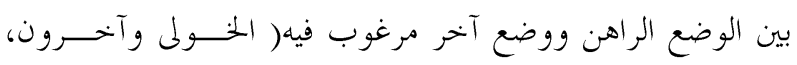

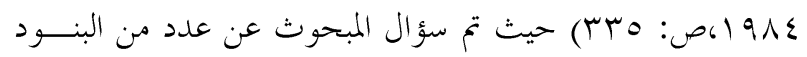

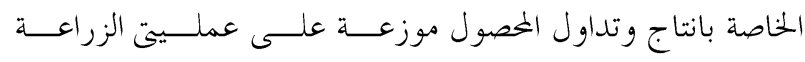

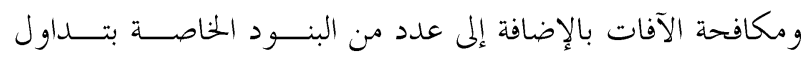
المحصول. ا- التوصيات الفنية لزراعة محصول الفول السودالي: ويمثلها rV

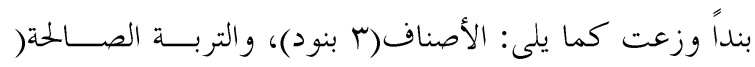

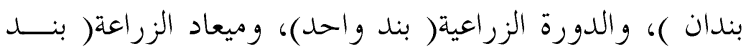

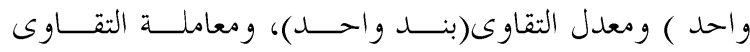
بالعقدين(بندان)، و الزراعة في حالة الرى بـــالغمر( ع بنــــود)،

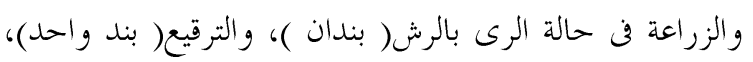

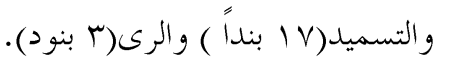

\section{r- التوصيات الفنية لمكافحة آفات محصول الفول الســودام:}

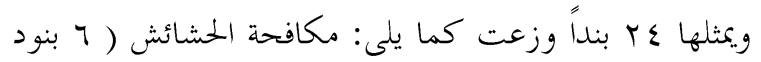

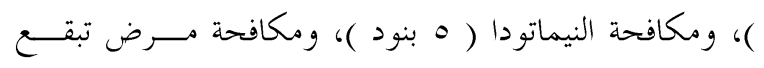

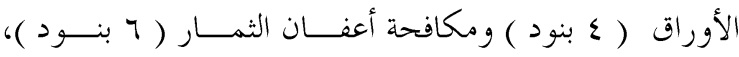

$$
\text { ومكافحة دودة ورق القطن ( س بنود ). }
$$

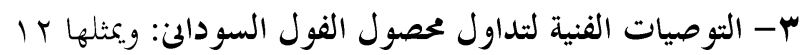

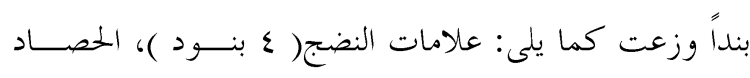

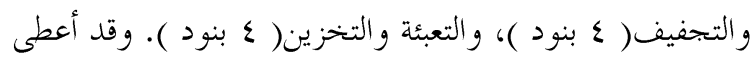

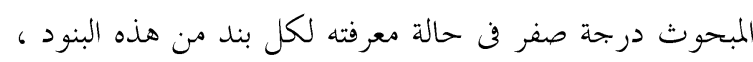

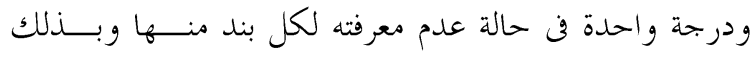

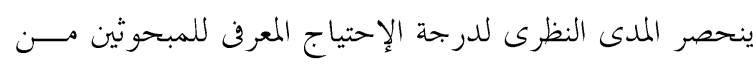

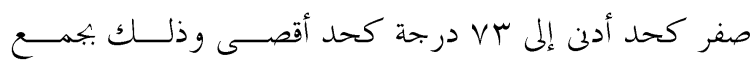

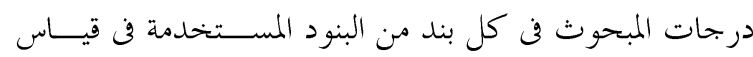
درجة الإحتياج المعرفى. ثانياً: المتغيرات المستقلة: 1- نوع الموهل الدراسى: قيس بإعطاء الحلاصل على بكــالوريوس

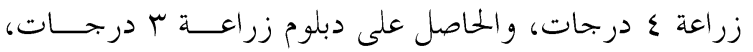


بإنتاجية هذا المحصول وزيادة العائد المتحقق من زراعتــه وبالتــالى

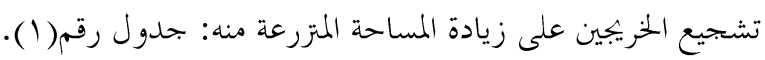

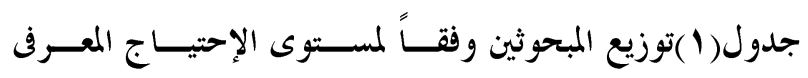

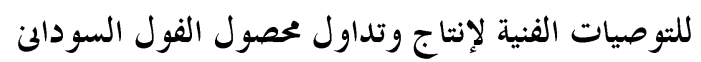

\begin{tabular}{|c|c|c|}
\hline$\%$ & عدد & مستوى الإحتيا ج المعرفي \\
\hline Ir,. & $r$ r. & منخفض (10 - \\
\hline$T \varepsilon, 9$ & $1 \ldots$ & متوسط ( - - ) \\
\hline Tr,I & $r \varepsilon$ & مرتفع (r T - - \\
\hline $1 \ldots$ & $10 \leqslant$ & ابجالى \\
\hline
\end{tabular}

وباستعر اض تفاصيل الإحتياج المعرف للتوصيات الفنية لزراعـــة

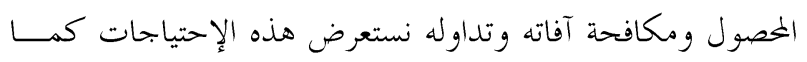
يلى:

توضح البيانات الواردة بالجحدول رقم( r ) مستوى الإحتيــاج

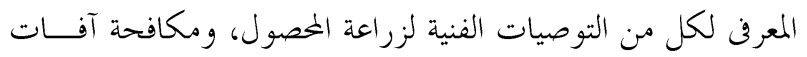
المصصول، و التوصيات الفنية لتداوله، ومنه يتبن أن مستوى الإحتياج المعرفى بكل من التوصيات الفنية لزراعة الفول السودانى، و التوصيات

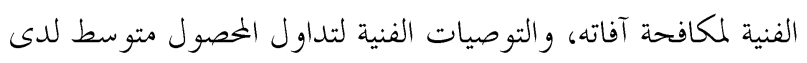

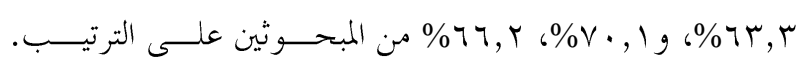

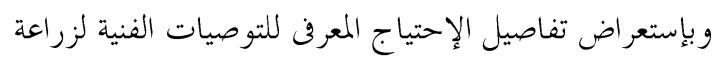

جدول ب. توزيع المبحوثين وفقاً لمستوى عناصر الإحتياج المعرفى للتوصيات الفنية لزراعة ومكافحة آفات وتــداول محصــول

\begin{tabular}{rrrrr} 
& & & \\
\hline \\
\hline
\end{tabular}

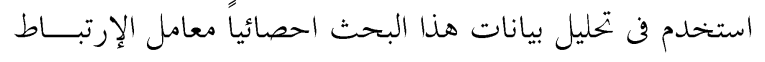

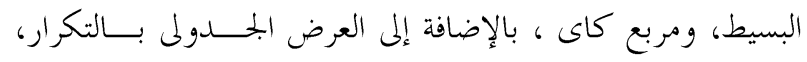

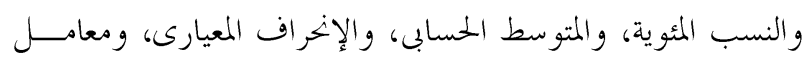
الإختلاف.

\section{النتائج ومناقشتها}

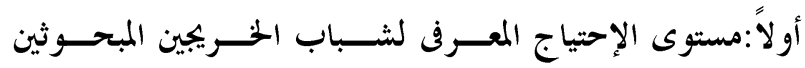
للتوصيات الفنية لإنتاج وتداول محصول الفول السوداني:

تراوح المدى الفعلى لدرجة الإحتياج المعرفى لشباب الخـــيجين

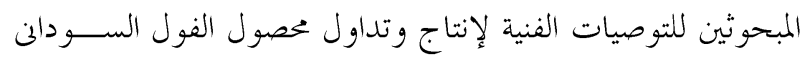

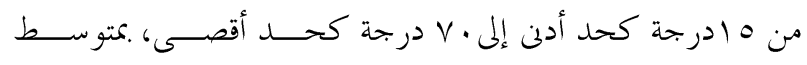

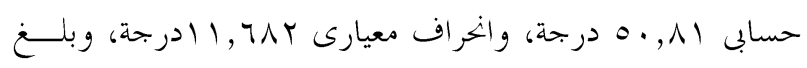

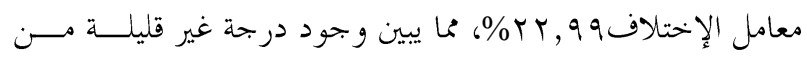
الإختلاف بين المبحوثين في درجة إحتياجهم المعرفى للتوصيات الفنية

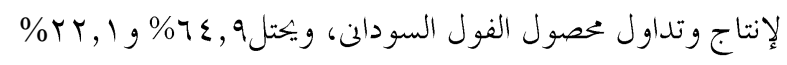

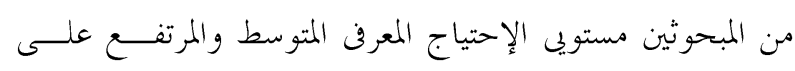

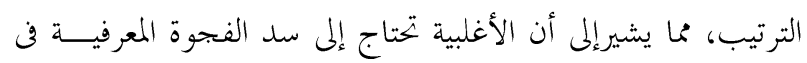

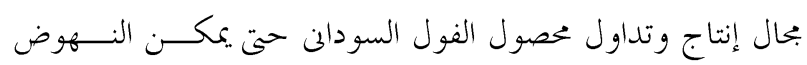
جدول r. توزيع المبحوثين وفقاً لمستوى عناصر الإحتياج المعرف

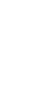




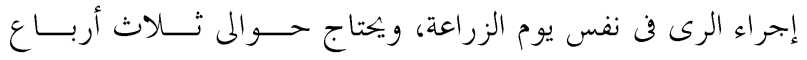

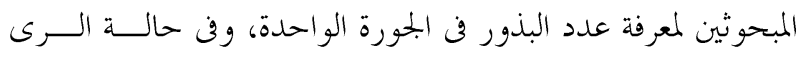

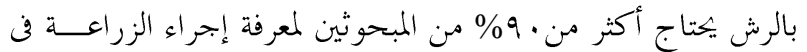

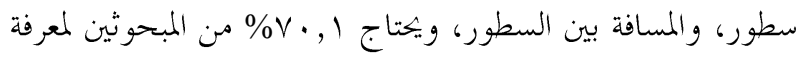
توصية إجراء الترقيع بعد ·ـ أيام من الزراعة.

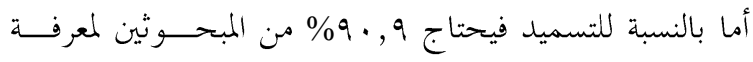

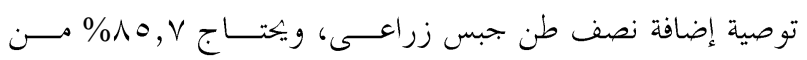

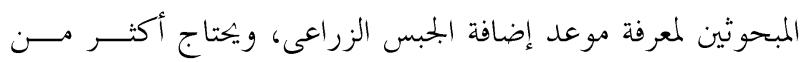

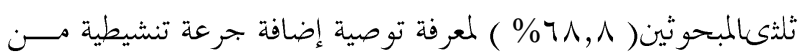

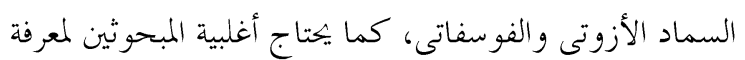

المحصول ومكافحة آفاته وتداوله وفقاً لبنود قياس المتغير التابع نتناولها

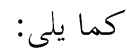

\section{1- الإحتياج المعرفى للتوصيات الفنية لزراعة الفول السوداني:}

تظهر البيانات الواردة بالجمدول رقم( r ) أن جميع المبحــــئين

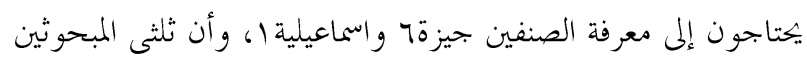

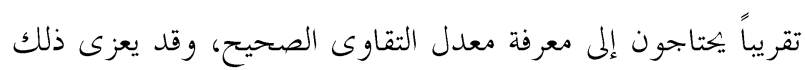

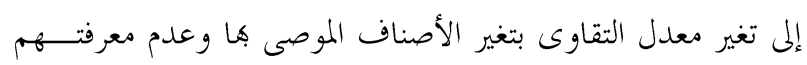

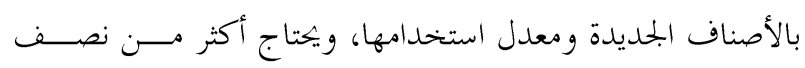

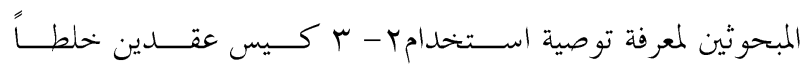

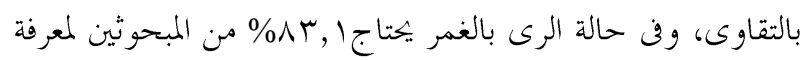

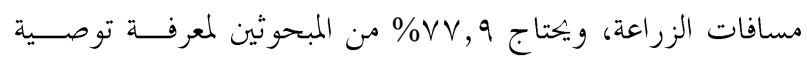

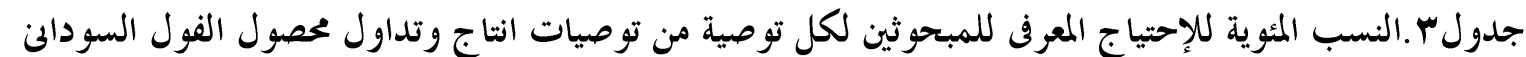

\begin{tabular}{|c|c|c|c|c|c|}
\hline \multicolumn{2}{|c|}{ الإحتياج المعرفى" } & \multirow[t]{2}{*}{ التوصيات الفنية } & \multicolumn{2}{|c|}{ الإحتياج المعرفى* } & \multirow[t]{2}{*}{ التوصيات الفنية } \\
\hline$\%$ & عدد & & $\%$ & عدد & \\
\hline$\uparrow \wedge, \wedge 1$ & 1.7 & - دفعة أولى من السماد (تنشيطية ) & & & أولا : الإحتياج المعرفى للتوصيات الفنية \\
\hline$\leqslant \wedge, 1$ & $V \varepsilon$ & أ- ... أكجم نترات & & & لزراعة الفول الكوداني : \\
\hline $0 \xi, 0$ & $\wedge \varepsilon$ & ب - . . ا كجم سوبر فوسفات & $\varepsilon r, q$ & 74 & 1- الأصناف : 1- جيزة 0 \\
\hline 71, & $9 \varepsilon$ & دفعة ثانيةبعد اسبوعين من الزراعة & $1 \ldots$ & $10 \varepsilon$ & 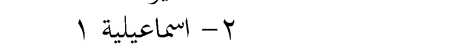 \\
\hline$\vee \vee, q$ & ir. & أ - . ـ كجم نترات & $1 \ldots$ & $10 \varepsilon$ & T- T- T T \\
\hline$V \vee, q$ & M. & ب- .0 كجم سوبر فوسفات & & & ץ- التربة الصالحة للزراعة: \\
\hline$\Lambda \bullet, \mathrm{v}$ & ITr & دفعة ثالثة بعد شهر من الزراعة & $0, Y$ & $\wedge$ & بلية \\
\hline $9 \varepsilon, \wedge$ & $1 \leqslant 7$ & أ - . . كجم نترات & rq,. & 7. & صفر اء خفيفة \\
\hline $9 r, 0$ & $1 \leqslant \varepsilon$ & ب - . مكجم سوبر فوسفات & $\vee, \wedge$ & ir & r- الدورة الزراعية (ثنائية/ثلاثية) \\
\hline ov, 1 & $\wedge \wedge$ & إضافة . . 1 كجم سلفات بوتاسيوم & $\vee, \wedge$ & ir & 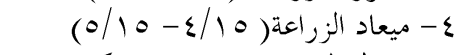 \\
\hline & & رش العناصر الصغرى : & $7 T, Y$ & $1 \cdot r$ & ه- معدل التقاوى ( 0ـ - .0 كجم ) \\
\hline$r \wedge, \uparrow$ & $\varepsilon \varepsilon$ & الرشة الأولى بعد شهر من الزراعة & & & 7- معاملة التقاوى بالعقدين \\
\hline$\varepsilon \cdot, r$ & Tr & الرشة الثانية بعد ــم يوم من الزراعة & $0 \leqslant, 0$ & $\wedge \varepsilon$ & استخدام ( ץ-rكيس للفدان ) \\
\hline $9 r, 0$ & $1 \varepsilon \varepsilon$ & معدل العناصر الصغرى ه..,. ·تر/فدان & $\varepsilon \cdot, r$ & Tr & الزراعة في نفس يوم المعاملة \\
\hline$u, \wedge$ & 1.7 & 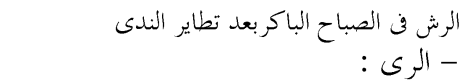 & & & 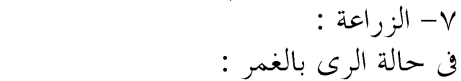 \\
\hline$\Delta r, 1$ & IrA & في حالة الرى بالغمر ع - 7 م & $T r, r$ & 97 & تتم الزراعة على (ז اخط/قصبتين ) \\
\hline $9 \vee, \varepsilon$ & 10. & في حالة الرى بالرش يوم بعد يوم & $\wedge r, 1$ & Irs & مسافات الزراعة م \\
\hline \multirow[t]{3}{*}{$\uparrow \wedge, \wedge$} & 1.7 & يوقٍِ الرى قبل أسبوعين من الحصاد & $v \varepsilon$, & $11 \varepsilon$ & عدد البذور في الجورة \\
\hline & & 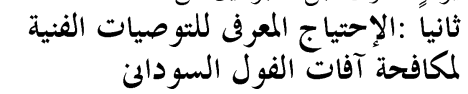 & $\vee v, q$ & ir. & الز الزى في نفس يوالة الرى الز بالرشة : \\
\hline & & 1- مكافحة الحشائش : & $9 \varepsilon, \wedge$ & $1 \leqslant 7$ & تتم الزراعة على سطور \\
\hline$r \cdot, \Lambda$ & rt & - العزيق r- r عزقة & $9 \cdot, 9$ & $1 \varepsilon$. & المسافة بين السطور • ـسم \\
\hline$\Delta r, 1$ & IrA & - إعطاء رية كدابة & $v \cdot, 1$ & $1 \cdot 1$ & ^-إجراء الترقيع بعد ·ـ أُيام من الزراعة \\
\hline$v \cdot, 1$ & $1 \cdot 1$ & - مبيد استومب للحشائش النجيلية الحولية & & & 9- التسميد : \\
\hline$\vee v, q$ & ir. & - استومب التر للفدان & $r, T$ & $\varepsilon \wedge$ & اضافة • ب ع سماد بلدى للفدان \\
\hline$\varepsilon 1, \uparrow$ & $7 \varepsilon$ & - مبيد فيوزبليدللحشائش النجيلية المعمرة & $9 \cdot, 9$ & $1 \varepsilon$. & اضافة //اطن جبس زراعى للفدان \\
\hline$\varepsilon 7, \wedge$ & vr & - الفيوزبليد التر للفدان & $\Lambda 0, \mathrm{~V}$ & Irt & الإضافة بعد هـ-. -عيوم من الزراعة \\
\hline
\end{tabular}




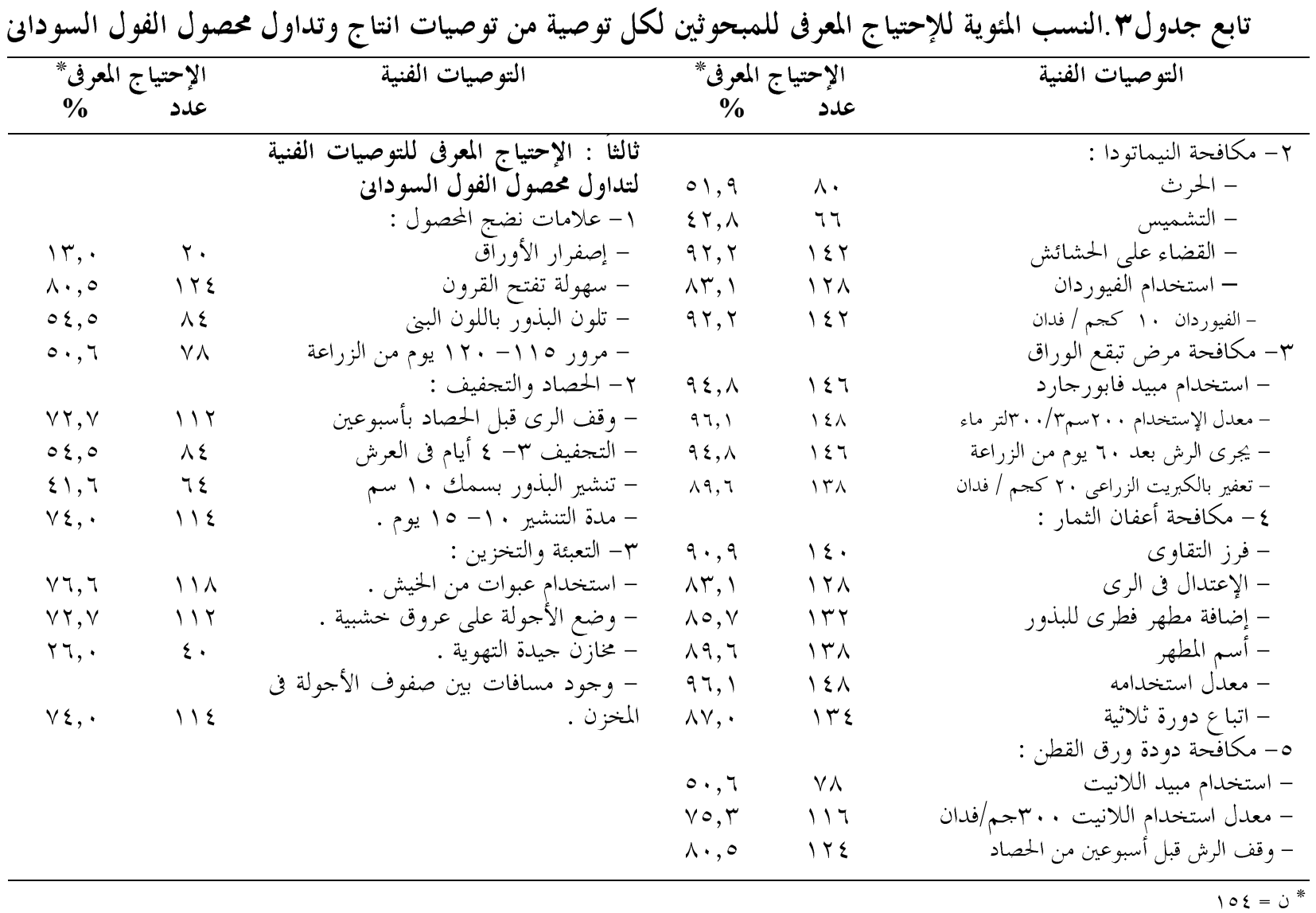

كدابة، واستخدام مبيد استومب لمكافحة الحشائش الحولية ومعدل

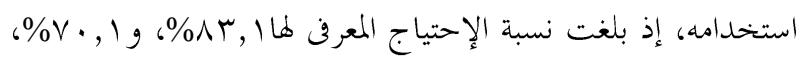
\% من \% و المبحوثين على الترتيب. اما بالنسبة لمكافحة النيماتودا فيحتاجr, ب9 \% من المبحوثين إلى كأل معرفة توصية القضاء على الحشائش كأسلوب لمكافحة النيمــاتودا،

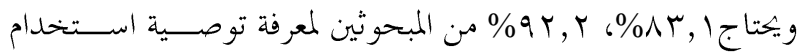

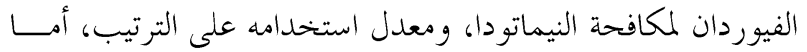

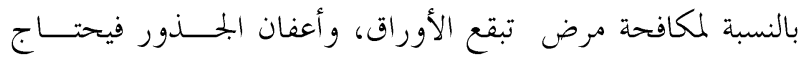

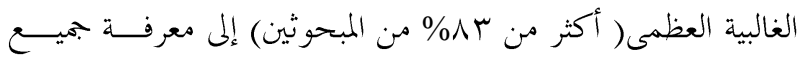

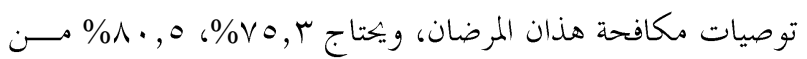
المبحوثين إلى معرفة معدل استخدام مبيد اللانيت ضسـد دودة ورق القطن، وتوصية وقف الرش قبل الحصاد بأسبوعين على الترتيب. ب- الإحتياج المعرفى للتوصيات الفنية لتداول محصــول الفــول

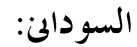

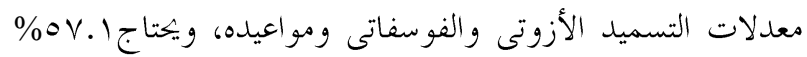

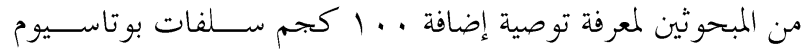

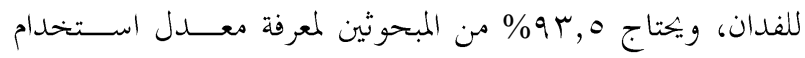

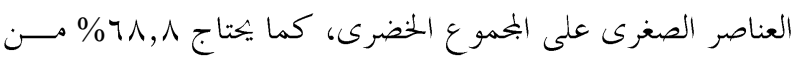
المبحوثين لمعرفة توصية رش العناصر الصغرى فن الصباح بعد تطاير

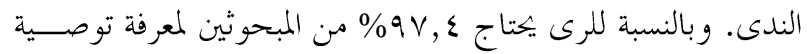

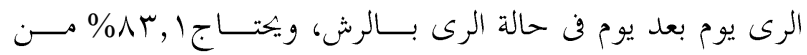

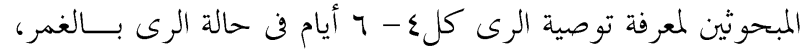
ويحتاج أكثر من ثلثى المبحوثين لمعرفة توصية وقف الرى قبل الحصاد

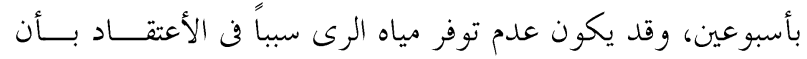

$$
\text { طول الفترة بين الريات هى المو اعيد الموصى هـا. }
$$

\section{Y- الإحتياج المعرفى للتوصيات الفنية لمكافحة آفــات الفــول}

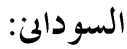

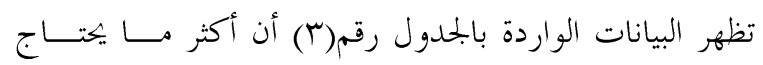

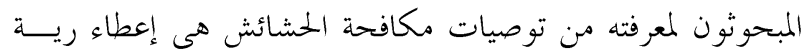


سنوات الخبرة في بحال زراعة الفـــول الســودانف كمــتغيران

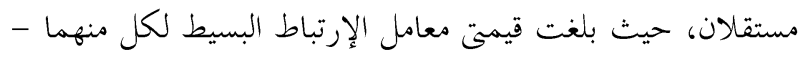

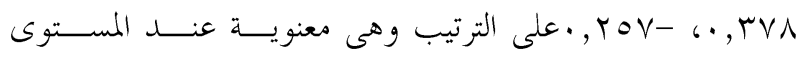

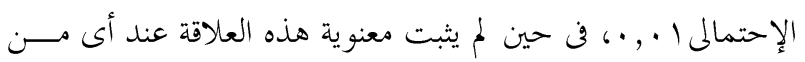

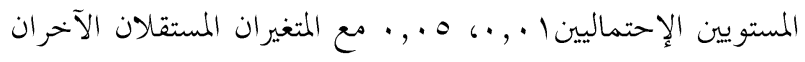

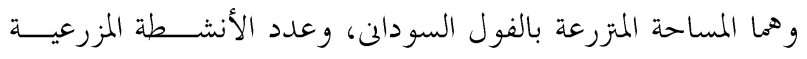

لمبحوث.

جدولع ـ معامل الإرتباط البسيط بين بعـض المــتغيزات المســتقلة

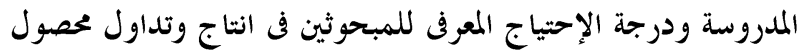
الفول السوداني كمتغير تابع

\begin{tabular}{|c|c|c|}
\hline المعنوية *ـتوى & $\begin{array}{l}\text { الإرتباط } \\
\text { البسيط }\end{array}$ & 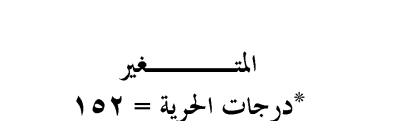 \\
\hline תזים. & $.01 . .-$ & حجم المساحة المتزرعة بالفول السودالين \\
\hline$\cdot, \cdot, 1$ & *** Yov.. - & عدد سنوات الحخبرة في زراعة الخصول \\
\hline$\cdot, \cdot 7$ & Iro. - & عدد الأنشطة المزرعية للمبحوث \\
\hline$\cdots$ & 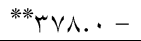 & درجة التعرض لمصادر المعلومات الإرشادية \\
\hline
\end{tabular}

وبناء على ماتقدم أمكن رفض الفرض الإحصائى السابق بالنسبة الإرفادية

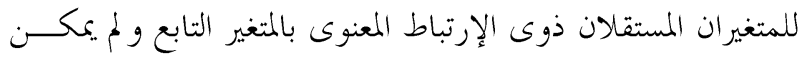
رفضه بالنسبة للمتغيران الآخران، ومن هذا يتبين أهمية دور الإرشاد

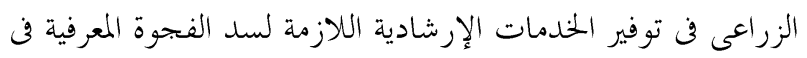

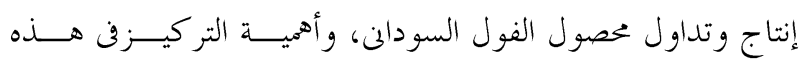

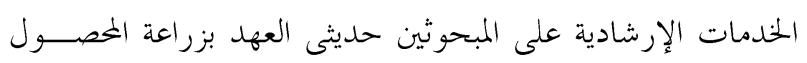
حتى يمكن اشباع احتياجاهم المعرفية في هذا الجحال. ولتحقيق الفرض البحثى الثانى تم صياغة الفـــــ الإحصــائى

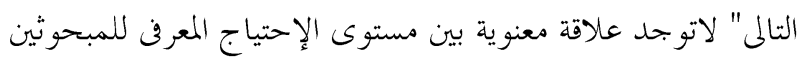

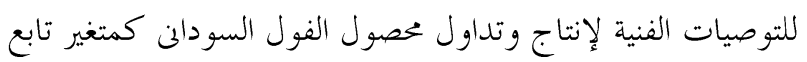

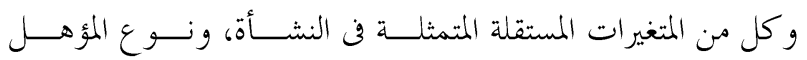

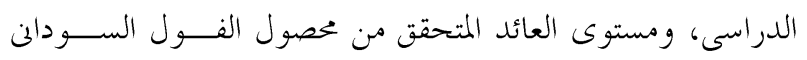

$$
\text { كمتغيرات مستقلة". }
$$

بالنسبة لعلامات نضج المحصول تظهر البيانات الواردة بالجدول

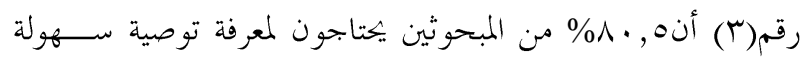

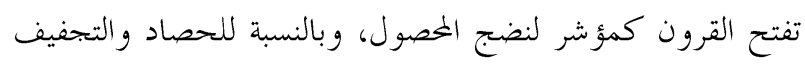

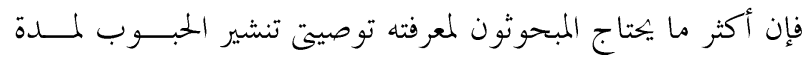

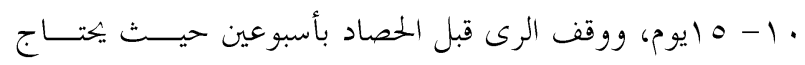

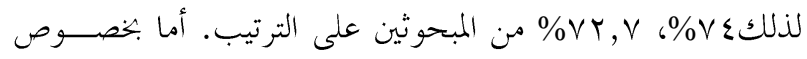

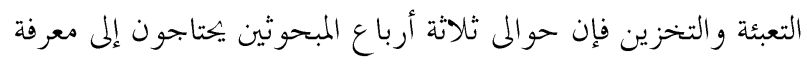

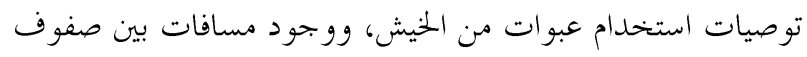

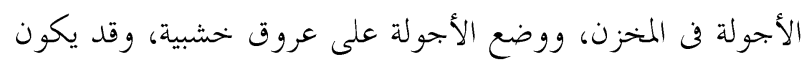

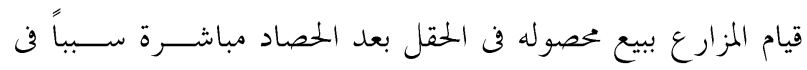

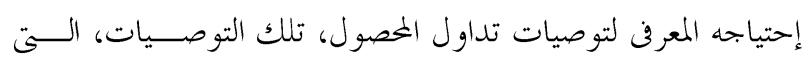

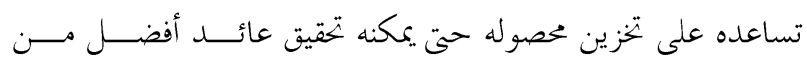
تسو يقه.

ثانياً: تحديد العلاقة بين الإحتياج المعرفى للمبحوثين للتوصسيات الفنية لإنتاج وتداول محصول الفول السودالن والمتغيرات المستقلة

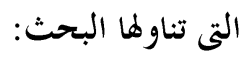
تحقيقاً للفرض البحثى الأول تم صياغة الفرض الإحصائى التالى "

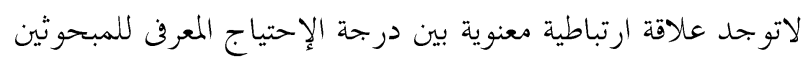

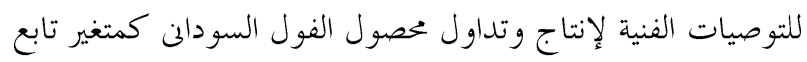
وكل من المتغيرات المستقلة المتمثلة في حجم المساحة المترعة بالفول

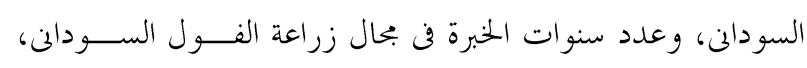

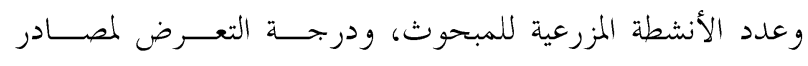

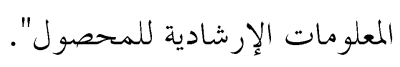
و باختبار هذا الفرض باستخدام معامل الإرتباط البسيط تظهــر

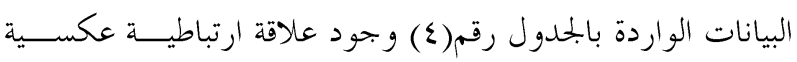

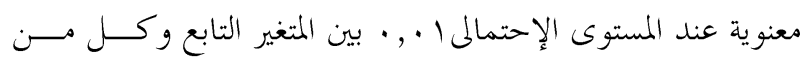

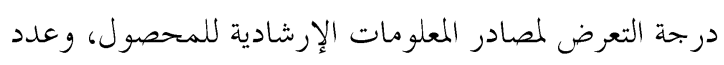

جدوله ـ قيمة كاب للعلاقة بين بعض المتغيرات المستقلة المدروسة ومستوى الإحتياج المعرفى للمبحوثين فى انتــاج وتســويق محصول الفول السوداني كمتغير تابع

\begin{tabular}{|c|c|c|c|c|}
\hline درجات & كاب الجدوليةعند & عاب كالجدول. & كاY & 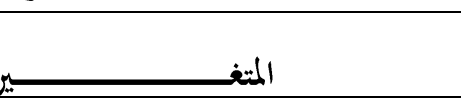 \\
\hline 7 & $17, \wedge 1$ & $1 r, 09$ & $* 10,7 \varepsilon$ & نو ع المؤهل الدراسى \\
\hline r & $9, Y)$ & 0,99 & $\varepsilon, \leqslant 97$ & النشَّة \\
\hline$\varepsilon$ & $\mid r, r \wedge$ & $9, \leqslant 9$ & $* * \leqslant 7, \vee 9$ & مستوى العائد الصاف من المصصول \\
\hline
\end{tabular}




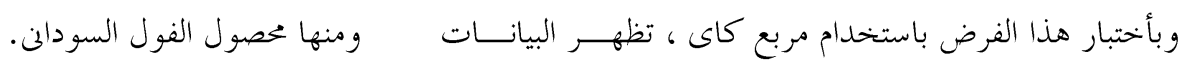

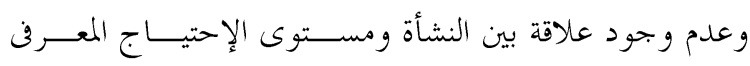

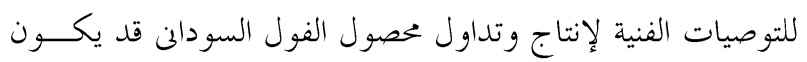

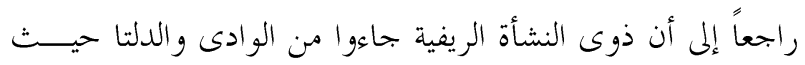

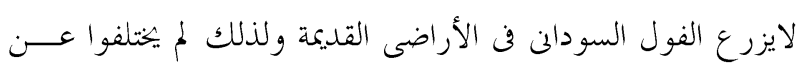

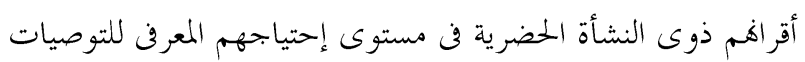
الفنية لإنتاج وتداول المصول.

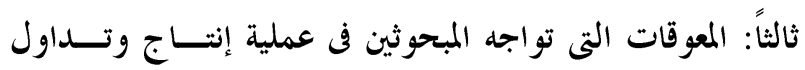
محصول الفول السوداني:

تمثلت المعوقات التئ تواجه المبحوثين في عملية إنتاج وتـــــاول

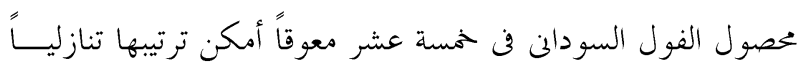
وفقاً لتكرارات ذكر المبحوثين لها جدول رقم(ج) على النحو التهو التالى:

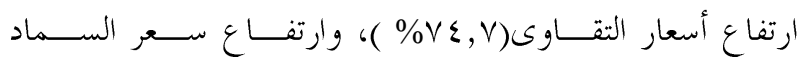

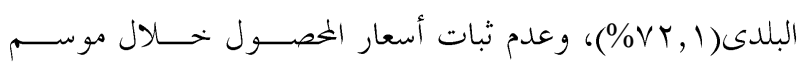

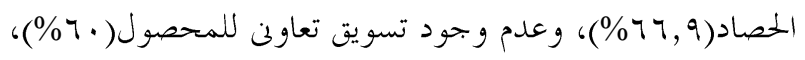

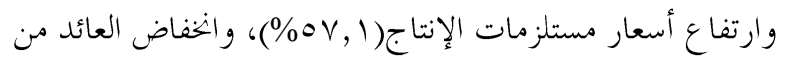

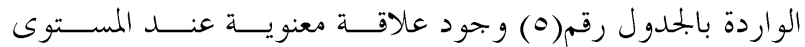

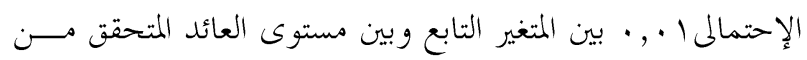

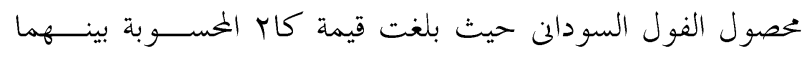

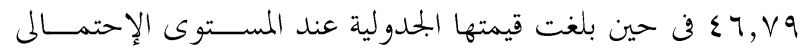

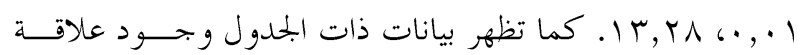
معنوية عند المستوى الإحتمالى ه ., ·. بين المتغير التابع و نوع المؤهل

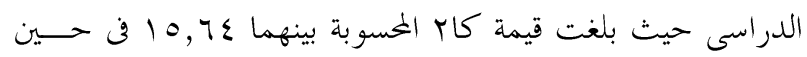

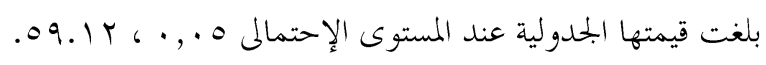

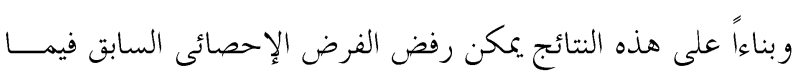

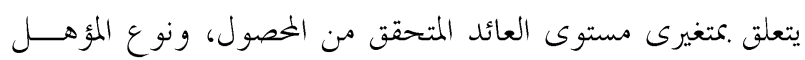

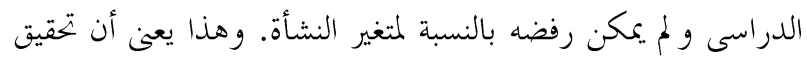

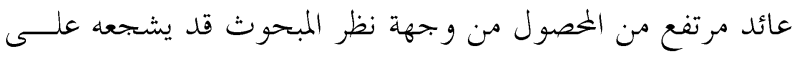

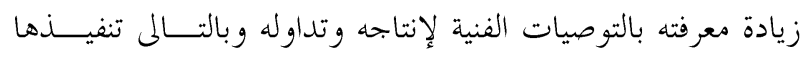

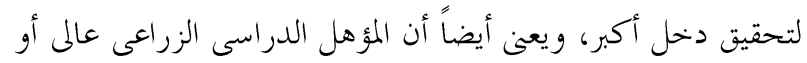

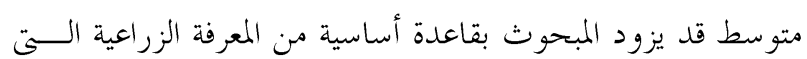

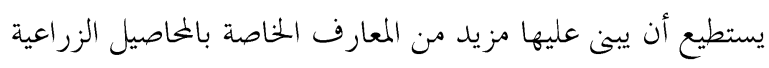
جدول ج . المعوقات التى تو اجه المبحوثين في عملية انتاج وتداول محصول الفول السودادين

\begin{tabular}{|c|c|c|}
\hline$* \%$ & 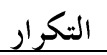 & 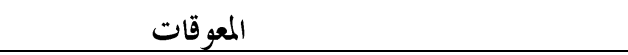 \\
\hline$v \varepsilon, V$ & 110 & 1- ارتفاع أسعار التقاوى \\
\hline$V r, 1$ & 111 & r- ارتفاع سعر السماد البلدى \\
\hline 77,9 & $1 \cdot r$ & r- عدم ثبات اسعار الخصول خلال موسم الحصاد \\
\hline $7 \cdot, \cdot$ & $9 \varepsilon$ & ع - عدم وجود تسويق تعاون للمحصول \\
\hline ov, 1 & $\wedge \wedge$ & ه- ارتفاع اسعار مستلزمات الإنتاج \\
\hline ov, 1 & $\wedge \wedge$ & ؟- انخفاض العائد من المصصول مقارنة بالخاصيل الآخرى \\
\hline 04,0 & $\wedge \vee$ & - قصور الجهود الإرشادية الخاصة بالخصول \\
\hline$\bullet \cdot, \cdot$ & VV & ^- ارتفاع نسبة السمسرة عند بيع الخصول \\
\hline$\varepsilon 9, \varepsilon$ & $v_{4}$ & 9- قلة مياه الرى \\
\hline$\varepsilon \wedge, \vee$ & vo & • 1- اصابة الأرض بالنيماتودا \\
\hline$\varepsilon \varepsilon, \wedge$ & 79 & 11 1 - عدم توفر التقاوى المنتقاة \\
\hline$\varepsilon r, r$ & 70 & r ا - ارتفاع تكلفة العمالة الزراعية للمحصول \\
\hline rr, & 01 & rا - انتشار الحشائش النجيلية بالحقول \\
\hline$r v, r$ & $\varepsilon r$ & ـ ا- عدم توفر سطارات لزراعة الخصول \\
\hline $1 \pi, 7$ & Yl & ه 1 - انخفاض المستوى الإقتصادى للمبحوثين \\
\hline
\end{tabular}


في ضوء النتائج التي أسفر عنها البحث أمكن التوصل إلى عـــد من المقترحات للنهوض بانتاج محصول الفول السودانى كمياً وكيفياً ه

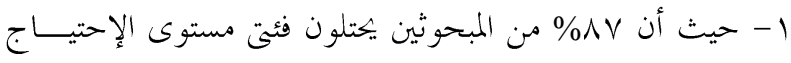

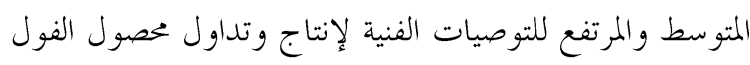
السودانى يقترح البحث تخطيط برنامج إرشادى يهدف إلى سد

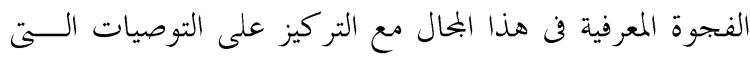

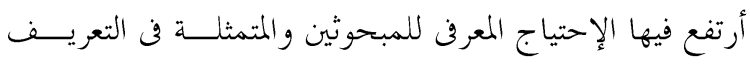

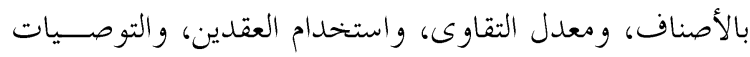

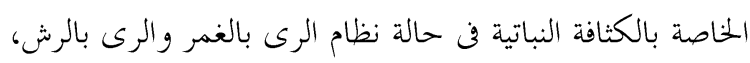

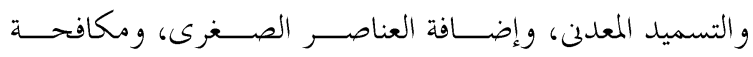

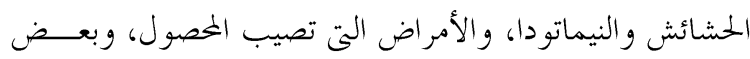
علامات نضج المصصول، وعملية التجفيف و التعبئة والتخزين. r- وفقاً لما أسفر عنه البحث عن وجود علاقة معنوية بين كل من

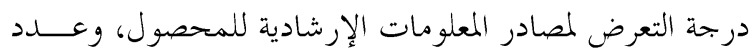

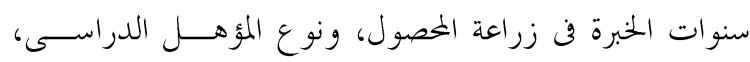

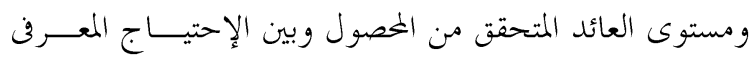

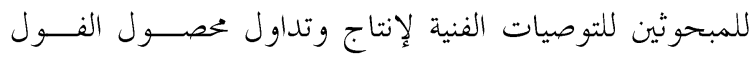

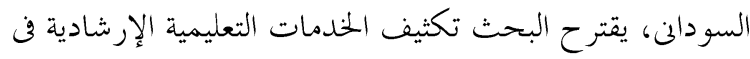

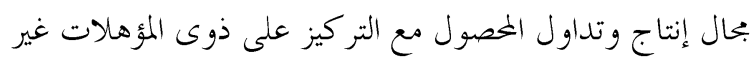
الزراعية، وقليلى الخبرة في زراعة المحصول، و الذين يحققون عائداً

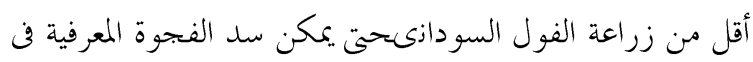

$$
\text { إنتاج وتداول الخصول لديهم. }
$$

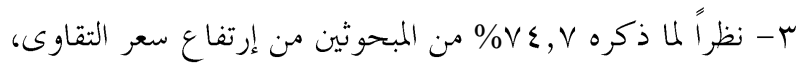
وما ذكره م, §ع\% من المبحوثين من عدم توفر التقاوى المنتقاة،

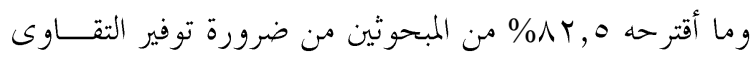

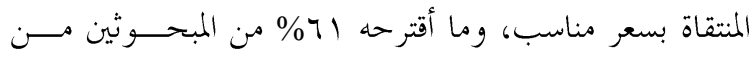

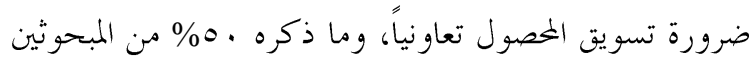

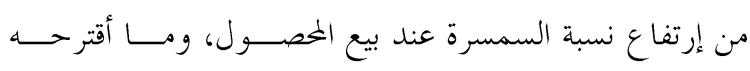

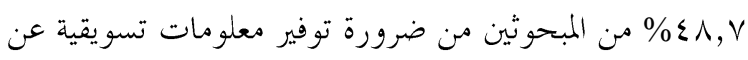

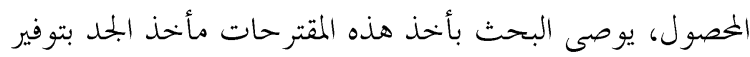

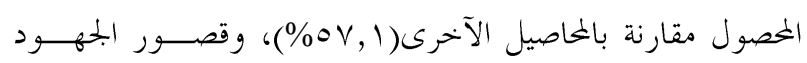

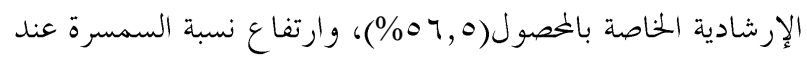

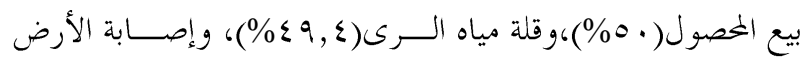

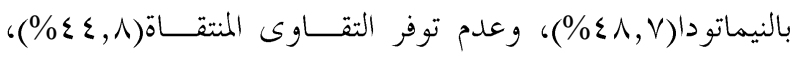

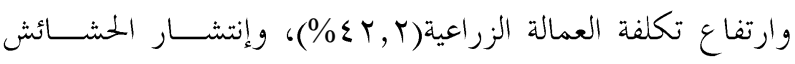

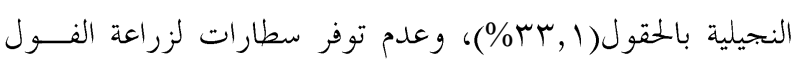

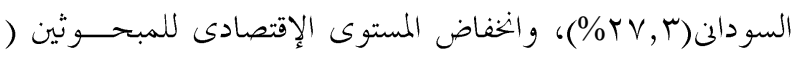
$.(\%) \Gamma, 7$ رابعاً: مقترحات المبحوثين للتغلب على معوقات انتاج وتــداول محصول الفول السوداني: تمثلت المقترحات التئ ذكرها المبحوثون للتغلب على معوقيــات

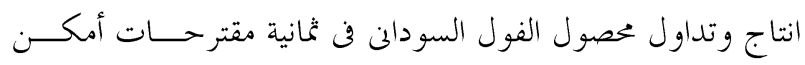

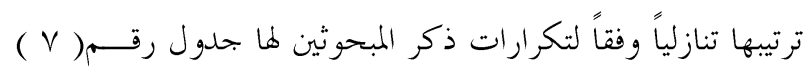

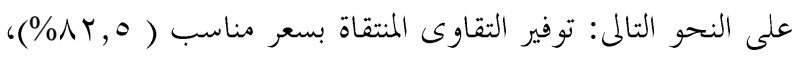

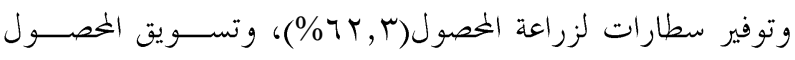

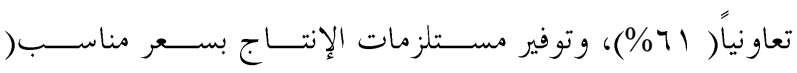

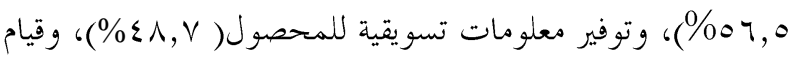

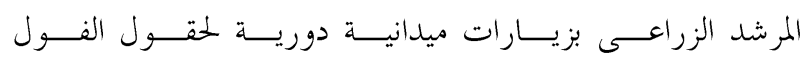

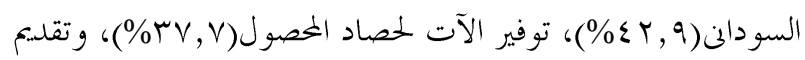

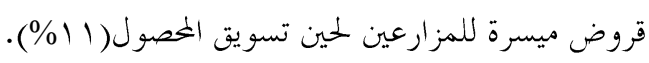
جدول V. مقترحات المبحوثين للتغلب على معوقات انتـــــاج وتداول محصول الفول السوداني

\begin{tabular}{|c|c|c|}
\hline *\% & النكرار & المقتر ح \\
\hline$\Delta r, 0$ & ITV & توفير التقاوى المنتقاة بسعر مناسب \\
\hline Tr, r & 97 & توفير سطارات لزراعة الخصول \\
\hline $7,$. & $9 \varepsilon$ & تسويق الخصول تعاونياً \\
\hline 07,0 & $\Delta \vee$ & توفير مستلزمات الإنتاج بسعر مناسب \\
\hline$\varepsilon \wedge, \vee$ & vo & توفير أخبار تسويقية عن الخصول \\
\hline$\varepsilon r, q$ & 47 & قيام المرشد بزيارات دورية لحقول الفول السوداني \\
\hline$r v, v$ & $0 \wedge$ & توفير الآت لحصاد الخصول \\
\hline $11,$. & iv & تقليع قروض ميسرة للزراع لحين تسويق الغخصول \\
\hline
\end{tabular}

\section{مقترحات البحث}




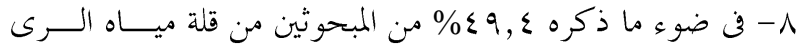

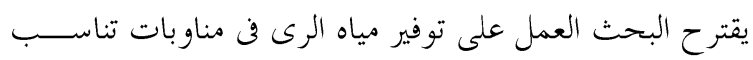

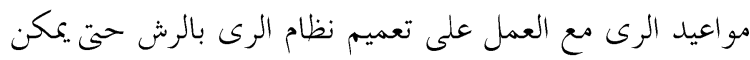

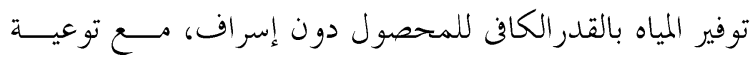

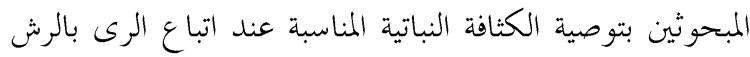
نظر اً لزيادة احتياجهم إلى معرفة هذه التوصيات.

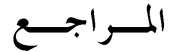

- الحفنى، محمد غانم، ( دكتــور )، المشــكلات البختمعيـة للمنــتفعين

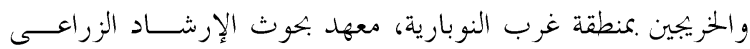

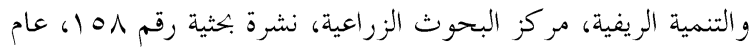
.1990

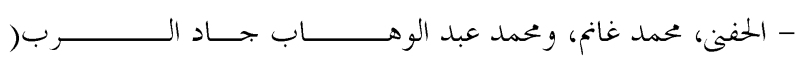

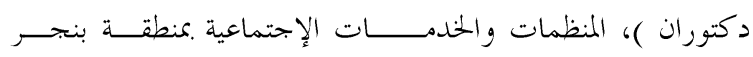
السكر ورضا الخريجين عنها، معهد بجوث الإرشاد الزراعى والتنمية

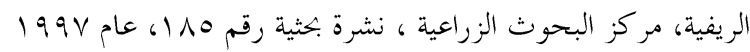

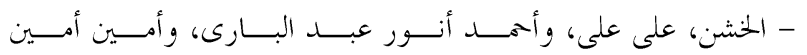

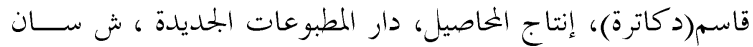

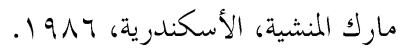
- الخولى،حسين زكى، وشادية فتحى، ومحمد فتحى الشاذلى (دكاترة)-

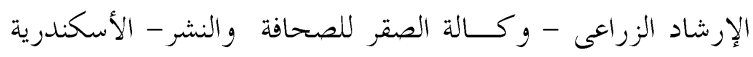

$.191 \varepsilon-$

- الطنوب، محمد عمر ( دكتور ) الــتغير الإجتمــاعى، دار المعسـارف

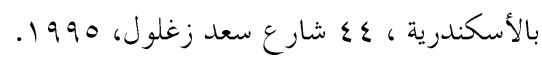
- العادلى، أحمد السيد، ( دكتور )، أساسيات علم الإرشاد الزراعى، دار

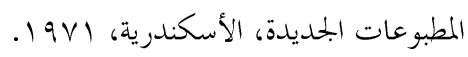
- المندوة، محى الدين محمد( دكتور )، الفول السودان، الصحيفة الزراعية،

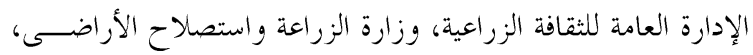

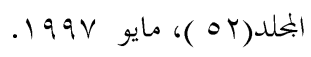

- بدران، شكرى محمد( دكتور )، الإحتياجات التعليمية للزراع المتنفعين

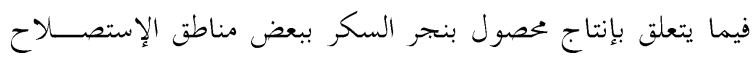

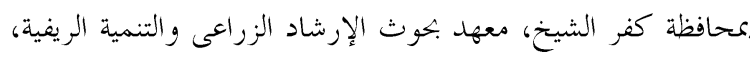

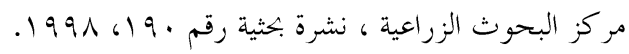

التقاوى المنتقاة، وتوفير المعلومات التسويقية التى تساعد الخريج على تسويق محصوله بسعر مناسب، مع إيجاد نظــام للتســـويق

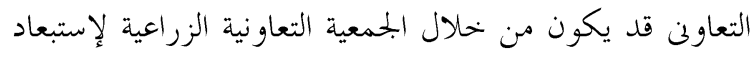
السماسرة والوسطاء.

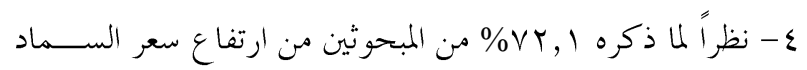

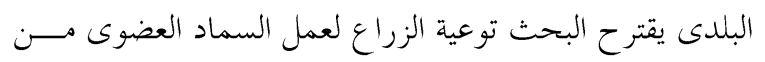

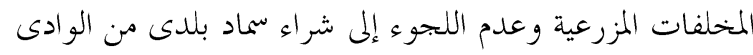

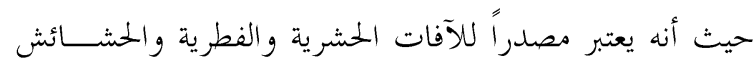

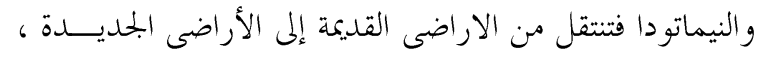

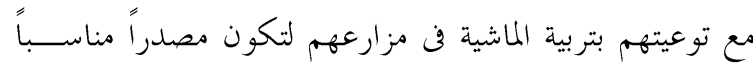

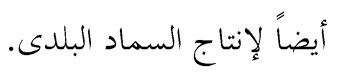

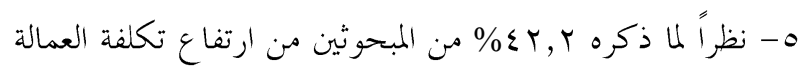

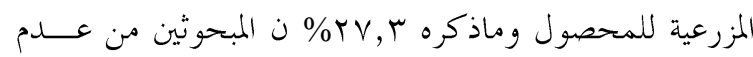

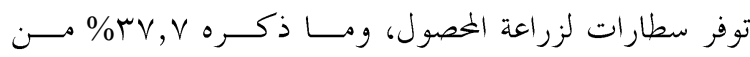

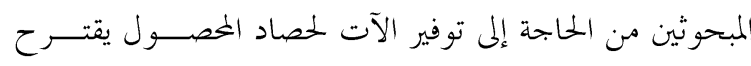

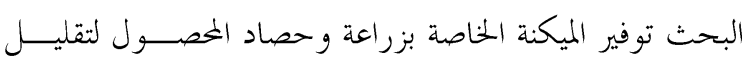

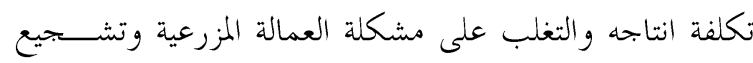
زيادة المساحة المتزرعة به.

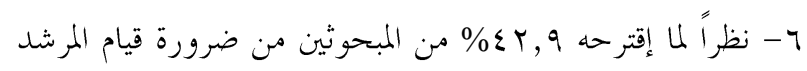

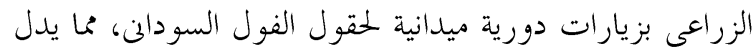

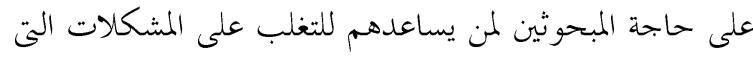

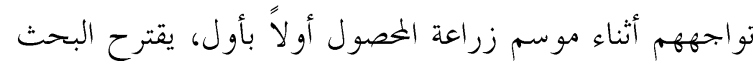
أن تكون زيارات المرشد بصفة دورية ومنتظمة ومعلومة المواعيد

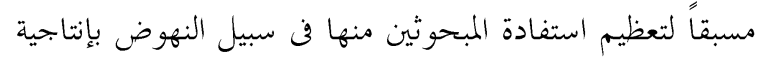

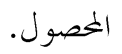

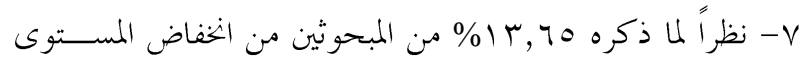

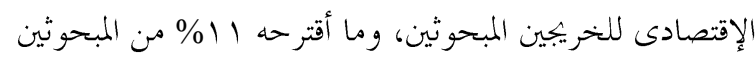

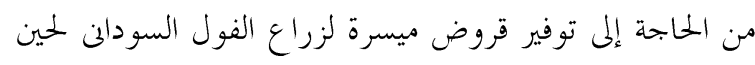

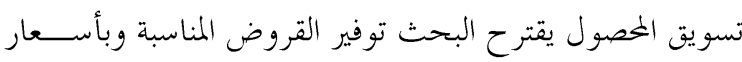

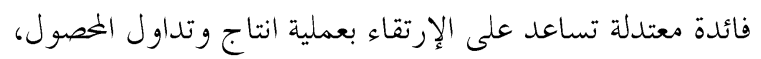
وتسدد بعد تسويقه. 
- عمار، عصام عبد اللطيف مبروك(دكتور)، دراسة الإحتياجات المعرفية

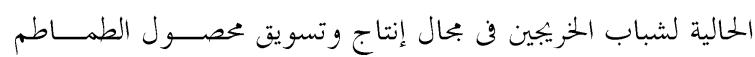

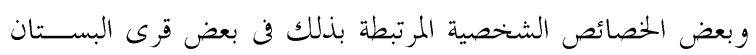

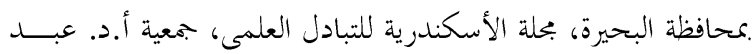

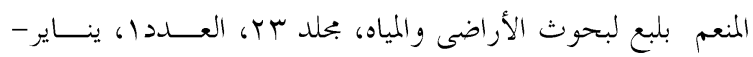
مارس، r. r. r. - محمد، ممدوح ابراهيم (دكتور)، عرش الفول السودافن لتغذية الحيوانات

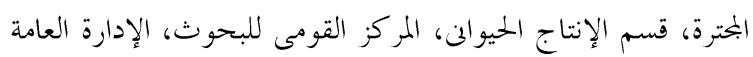

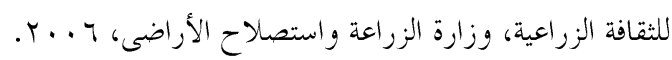

- Clark, Lorren," Definition of Want V s. Need" Graduate Student, Grand Valley Stat University. 2008.

http://WWWLearning to give: Org. copy right 2008 Learning to give, 1- Mars 2008.

-Ian Gough. "Economic Institutions and the Satisfaction of Human Needs. Journal of Economic Issues. Vol.28, no.1 (March 9), pp.25-66.1994.Julio Boltvinik Kalinka.2007.

http://el. Wikipedia. Org-27 May 2008.

-Maunder, H.(Edit.) "Agricultural Extension" A Reference Manual, Food and Agriculture organization of the United Nations, Rome, 1972.

-Vanden Ban, A.W and Haw Kins, H.S." Agricultural Extension "Longman Scientific and John Wiley \& Sons. Inc., New York 1988.

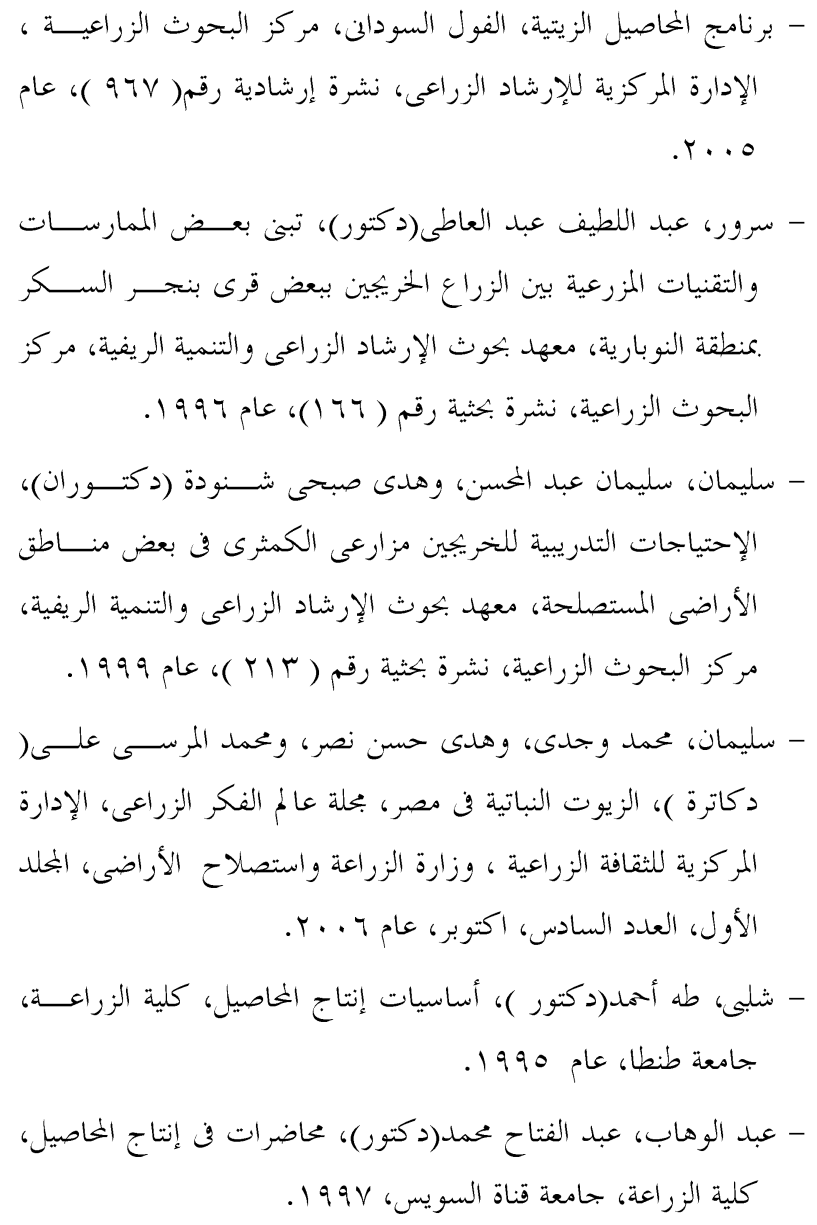




\title{
SUMMARY \\ Youth Graduates Agricultural Extension Knowledge Needs in Arachis Hypogeal Peanuts Producing and Handling in Boston Area, Beheira Governorate
}

\author{
Gamil M. Sharaf EL- Din, Esam Abd EL-Latif Ammar and Abd EL- Aaty Hemida Sokkar
}

This research aims to determine youth graduates knowledge needs level in Arachis hypogeal peanut producing and handling recommendations, determine the relationship between their knowledge need in Arachis hypogeal peanuts producing and handling recommendations and some independent variables, determine the restricts facing respondents concerning the crop producing and marketing, and their suggestions to overcome them. Data were collected from a random sample amounted to 154 respondents according to"Krejeci and Morgan" from Abd EL-Menem Reyad, Ahmed Ramy and EL-Sheikh Mohamed Refat villages, using a pretested questionnaire in Mars 2007.

Frequencies percentages, means, standard deviation, C.V.\%, simple correlation, and chi square were used to present and analyze data statistically.

The main results of the research are:

- $64.9 \%$, and $22.1 \%$ of the respondents with moderate and high need level of knowledge respectively concerning crop producing and handling recommendations.

- $63.6 \%, 70.1 \%$, and $66.2 \%$ of the respondents with moderate need level of knowledge concerning crop growing, pest management, and crop handling recommendations respectively, and $22.1 \%, 19.5 \%$, and $20.8 \%$ of the respondents with high need level of knowledge concerning crop growing, pest management and crop handling recommendations respectively .
- There is a significant negative correlation between degree of respondents' expouser to crop extension knowledge sources, and experience in crop growing as independent variables and degree of respondents' need of knowledge concerning crop producing and handling as a dependent variable

- There is a significant relationship between level of crop return and educational qualification quality as an independent variables and respondents need level of knowledge concerning crop producing and handling as a dependent variable.

The most important restricts facing respondents in Arachis hypogeal peanuts producing and marketing are: high price of seeds $(74.7 \%)$, high price of animal wastes $(72.1 \%)$ instability of crop price during harvest season $(66.9 \%)$, non cooperative marketing of crop (60.0\%), low level of crop return comparing with other crops $(57.1 \%)$, high cost of production inputs (57.1\%), shortage of agricultural extension efforts (56.5\%), and high ratio of commission in marketing the crop (50.0\%).

The respondents' suggestions to overcome these restricts are: Offering good seeds with a suitable price $(82.5 \%)$, using drill in planting process $(62.3 \%)$, cooperation marketing of the crop $(61.0 \%)$, suitable price of production inputs $(56.5 \%)$, offering marketing informations about the crop (48.7\%), and regular visits of agricultural extension worker to crop fields (42.9\%).Some important suggestions were mentioned to help respondents in Arachis hypogeal peanuts producing and marketing. 
